\section{Production Costs and Profitability for Selected Greenhouse Grown Annual and Perennial Crops: Partial Enterprise Budgeting and Sensitivity Analysis}

\author{
Xuan Wei \\ Mid-Florida Research and Education Center, University of Florida, 2725 S. \\ Binion Road, Apopka, FL 32703
}

Hayk Khachatryan

Food and Resource Economics Department and Mid-Florida Research and Education Center, University of Florida, 2725 S. Binion Road, Apopka, FL 32703

\begin{abstract}
Alicia Rihn
Mid-Florida Research and Education Center, University of Florida, 2725 S. Binion Road, Apopka, FL 32703
\end{abstract}

Additional index words. cost category, economic performance, ornamental plants, profit margin, risk

\begin{abstract}
In recent years, growers in the ornamental horticulture industry have experienced declining revenue and shrinking profit margins due to increased consumer spending captured by wholesale stores bypass, price competition at the retail level, as well as relatively low consumer demand. Maintaining cost-effective production practices is critical for nursery and greenhouse growers to stay profitable. However, a recent trend to impose more restrictive labeling polices on pesticide use (i.e., disclosing the use of neonicotinoids) may impact growers' already tightening production costs. A better understanding of the cost structure and production decision-making can provide insights for profitable operation. Using a partial enterprise budgeting approach, this research aims to evaluate production costs and profitability for $\mathbf{2 0}$ individual greenhouse annual and perennial crop production systems. Three primary economic performance indicators (net income, gross margin, and profit margin) were calculated and a sensitivity analysis was conducted to account for potential risks in production. Our results suggest that production costs vary significantly among different crops, thus implying that producers may have different profitability levels depending on the combination of crops grown. Our partial enterprise budgeting estimates serve as a reference point and can assist producers with reducing costs in specific areas, and aids in selecting and adjusting crop combinations to maximize potential profits. Sensitivity analysis scenarios provide insights to producers for evaluation of their entire operations and aid in making decisions on adopting alternative practices.
\end{abstract}

The ornamental horticulture industry provides important economic contributions to the U.S. agricultural sector. The 2013 U.S. Green Industry economic impacts (including indirect and induced effects in other sectors) were estimated at $\$ 196$ billion in output or revenues, $\$ 121$ billion in value-added contribution to the gross domestic product (GDP), and $\$ 82$ billion in labor income (Hodges

Received for publication 28 Oct. 2019. Accepted for publication 24 Jan. 2020.

Published online 27 March 2020.

H.K. is the corresponding author. E-mail: hayk@ ufl.edu.

This is an open access article distributed under the CC BY-NC-ND license (https://creativecommons. org/licenses/by-nc-nd/4.0/). vices, and nursery and floriculture production (Hall, 2010; Hodges et al., 2015a). The industry has experienced diminishing revenues in recent years due to considerable within-industry consolidation, increased price competition, and relatively weak consumer demand (Madigan, 2018). Therefore, maintaining low-cost and competitive production practices has become increasingly important for ornamental crop producers in the green industry. The 2003, 2008, and 2013 National Green Industry Survey revealed that growers reported that the "cost of production" was the top-rated factor affecting their price determination for their products in the past two decades (Brooker et al., 2005; Hodges et al., 2009, 2015b). The $2013 \mathrm{Na}$ tional Green Industry Survey inquired about the importance of factors affecting firms' competitiveness and performance, and growers gave "cost of production" an average rating of 3.41 on a 4-point Likert scale (4, very important; 3 , important; 2 , minor importance; and 1, not important). Furthermore, the percentage of surveyed growers who indicated "cost of production" as important or very important when determining price increased from $66.4 \%$ in 2007 (Hodges et al., 2009 ) to $87.0 \%$ in 2013 (Hodges et al., 2015b).

In 2018, the total production area of greenhouse operations (including glass, rigid plastic, and film plastic greenhouses) reached $423,013,000 \mathrm{ft}^{2}$, accounting for almost half of the total area of covered production (USDA NASS, 2019). This study focused on greenhouse production of annual and perennial crops not only because of its importance to the ornamental horticulture industry by providing out-of-season plant products but also because of the high level of risks (e.g., large investment, yield, and demand uncertainty) involved in greenhouse production. Greenhouse production is more capital-intensive than producing the same crop in the open field. Unlike fruits and vegetables, which are necessary goods for daily consumption, ornamental plants are often perceived as luxury products (International Association of Horticultural Producers, 2019; Schimmenti et al., 2013). Therefore, the demand for ornamental plants is highly elastic (Hovhannisyan and Khachatryan, 2016). Brand and Leonard (2001) showed that plant appearance, particularly for annual and perennial plants, was the most important quality attribute consumers consider when purchasing plants. Furthermore, yield is not guaranteed because even if a viable plant is grown to market size, any visual damage (along with plant disease, death, insect predation, etc.) can result in unsalable products. Related to plant value and yield uncertainty, plant disease control and prevention are important for reducing production risks and maintaining healthy, high-quality plants, which are demanded by end consumers. The use of pesticides to maintain plant quality represents a significant strategy of ornamental producers to stay competitive (Bethke and Cloyd, 2009). Neonicotinoids are the most effective insecticides for 
controlling sucking insect pests such as aphids and whiteflies (Jeschke and Nauen, 2008; Jeschke et al., 2011). Excellent plant virus vector control, high systemicity, versatile application methods, and long-lasting residual effects combined with high operator and consumer safety make them ideal tools for prophylactic protection from pest populations resistant to conventional insecticides and reduce risks attributable to pests (Elbert et al., 2008).

However, due to increased public attention to pollinator health (Biesmeijer et al., 2006; Colla and Packer, 2008; GemmillHerren, 2016; Ghazoul, 2005; Hill et al., 2019; Kleijn et al., 2015; Potts et al., 2010, 2016), several large retail stores in the United States have required labeling of the use of neonicotinoids pesticides during plant production, thus reflecting higher standards for production practices set by the consumers. Neonicotinoids have been banned in several European countries due to concerns about their impact on pollinator insect health (Goulson et al., 2015; Pisa et al., 2015; Sanchez-Bayo and Goka, 2014; van der Sluijs et al., 2013). Noleppa (2017) reviewed 13 studies and revealed that the neonicotinoid ban caused an average yield decrease of $4.0 \%$ in European oilseed rape production and an annual increase of production costs by at least 117. 5 million Euros after the ban in Europe solely due to the costs of extra foliar insecticide applications and associated application costs. Although seedcoating with neonicotinoids is widely performed for field crops, it is not used on the seeds of ornamental plants. In greenhouses, neonicotinoids are applied by granular soil incorporation, topical foliage sprays, or as a liquid soil drench (Nebraska Extension at University of NebraskaLincoln, 2016). Jactel et al. (2019) showed that the most common alternative to neonicotinoid insecticides is the use of another chemical insecticide ( $89 \%$ of cases). Nonetheless, other chemical insecticides are not necessarily safer for the environment because relative toxicities were not considered when comparing neonicotinoids with alternatives in their study. Furthermore, alternative pest management methods may not always match neonicotinoids in terms of efficacy, applicability, durability, and/or practicability. For example, Furlan and Kreutzweiser (2015) pointed out that widespread adoption of integrated pest management (IPM) approaches to insect pest management is particularly challenging when the use of neonicotinoid insecticides is large-scale and often prophylactic. IPM generally requires more labor and time and is managerial-intensive and informationextensive (Allahyari et al., 2017; Beckmann et al., 2009; Fernandez-Cornejo et al., 1994; Jones et al., 2009). Therefore, if a neonicotinoid ban occurred in the United States, then we would anticipate that the growers' cost of production would likely increase regardless of the alternatives adopted. In particular, labor costs are anticipated to increase due to increased application frequency if a less effective non-neonicotinoid chemical alternative is used; however, adopting more en- vironmentally friendly practices (i.e., IPM, organic production) are often more laborintensive. It is important to draw the growers' attention to the uncertainty embedded in the production process and inform them of potential cost changes associated with the adoption of alternative pest management practices (e.g., neonicotinoid-free production).

The purpose of this study was to present practical enterprise budgets and help growers to determine how the particular crop they are growing influences profitability. If producers need to decrease costs and increase profitability, then which cost component should be the primary focus? Will switching to a different production practice be economically feasible? By presenting cost estimates and primary economic performance indicators for selected individual annual bedding and perennial crops, we illustrated a great deal of variability in production costs and profitability across crops. This information will help growers determine which crops are relatively profitable. So far, such information has been neglected in enterprise budgeting analyses of ornamental production. By comparing and aggregating a set of crops similar to those in our study, growers can identify their operational efficiency. Furthermore, our sensitivity analysis provided two applications to risk situations associated with input costs. Growers can make necessary modifications to reflect their own situations and determine if the adoption of alternative pest management practices is economically feasible. With increasing environmental concerns related to pesticides and consumer demand for sustainable products, it is important for growers to be forwardlooking and prepared to meet these challenges. In this study, 20 representative annual bedding and perennial plants were selected based on the rankings of sales values reported in the 2014 USDA NASS Survey results. The complete plant list and sales rankings are summarized in Tables 1 and 2 . The uncertainty regarding the input cost is represented by changes in pesticide and chemical costs and changes in labor costs, which can be caused by switching to alternative pest management practices or substitutions between labor and intensive management of chemicals.

\section{Methods}

Partial budgeting is a commonly used economic tool that shows the effects of changes in production operations and assesses the economic profitability of an alternative production practice. The basic principles of partial budgeting include focusing only on the changes in income flows and/or expenses such as added income, reduced costs, reduced income, and increased costs (Kay et al., 2011). In this study, we focused on changes in production costs as a benchmark case. The adoption of alternative pest management practices will produce the same yield or higher. There is no associated increased or decreased income. Production costs were separated into detailed input items within three broad cost categories: direct costs, labor costs, and overhead costs associated with daily operations. Partial budgeting was combined with sensitivity analyses to measure the differences between the changes in agrichemical costs and labor costs. The study also examined the effects on common economic performance induced by changes in production costs. A sensitivity analysis of labor and agrichemical costs was performed to demonstrate the economic impact of changes on the aforementioned costs while keeping other cost variables and yield constant.

Partial budgeting analysis: Assumptions. The supporting assumptions are based on U.S. Department of Agriculture (USDA) survey data combined with the knowledge and experience of agricultural economists, extension horticulturists, and ornamental plant producers. According to the definition of partial budgeting analysis, upfront fixed investment costs that are unchanged (such as land lease/purchase or greenhouse construction costs) are suppressed. Using the greenhouse production area information reported in the Floriculture Crops 2018 Summary (USDA NASS, 2019), we estimated that the average production area would be $\approx 100,000$ $\mathrm{ft}^{2}$ for operations with a sales value of at least $\$ 10,000$ and $\approx 200,000 \mathrm{ft}^{2}$ for operations with a sales value of $\$ 100,000$ or more (Supplemental Table 1). Fisher et al. (2014) considered an example of $100,000 \mathrm{ft}^{2}$ to produce 250,000 1-gallon plants, but they did not specify whether the 250,000 1-gallon plants in their analysis were one single crop or multiple crops. Given that greenhouses typically produce multiple crops, we scaled down the square footage to a $20,000-\mathrm{ft}^{2}$ area $(\approx 0.46$ acres) because that area was designated for the production of a single annual or perennial crop in this analysis. To reflect the actual products available in retail outlets and accommodate different production practices, the finished plant sizes considered were 4-inch containers and six-pack flats for annual bedding plants and 1-gallon containers for perennial plants. Therefore, the representative producer is assumed to start with either 100,000 plants for a finished size of 4-inch containers or 50,000 plants for a finished size of six-pack flat and 1-gallon containers (see Tables 1 and 2 for detailed information). The cost of growing media is calculated based on the finished container sizes (Fisher et al., 2014). The growth period was then specified for each of the 20 crops and their corresponding finished sizes (Dole and Wilkins, 1999). The growth period was used to calculate fertilizer and chemical usage and associated costs (Hinson et al., 2008). It is worth noting that due to variations in production practices within the green industry, individual growers may have different production schedules depending on whether they start from seed germination or different stages of propagation or transplants. The growth 


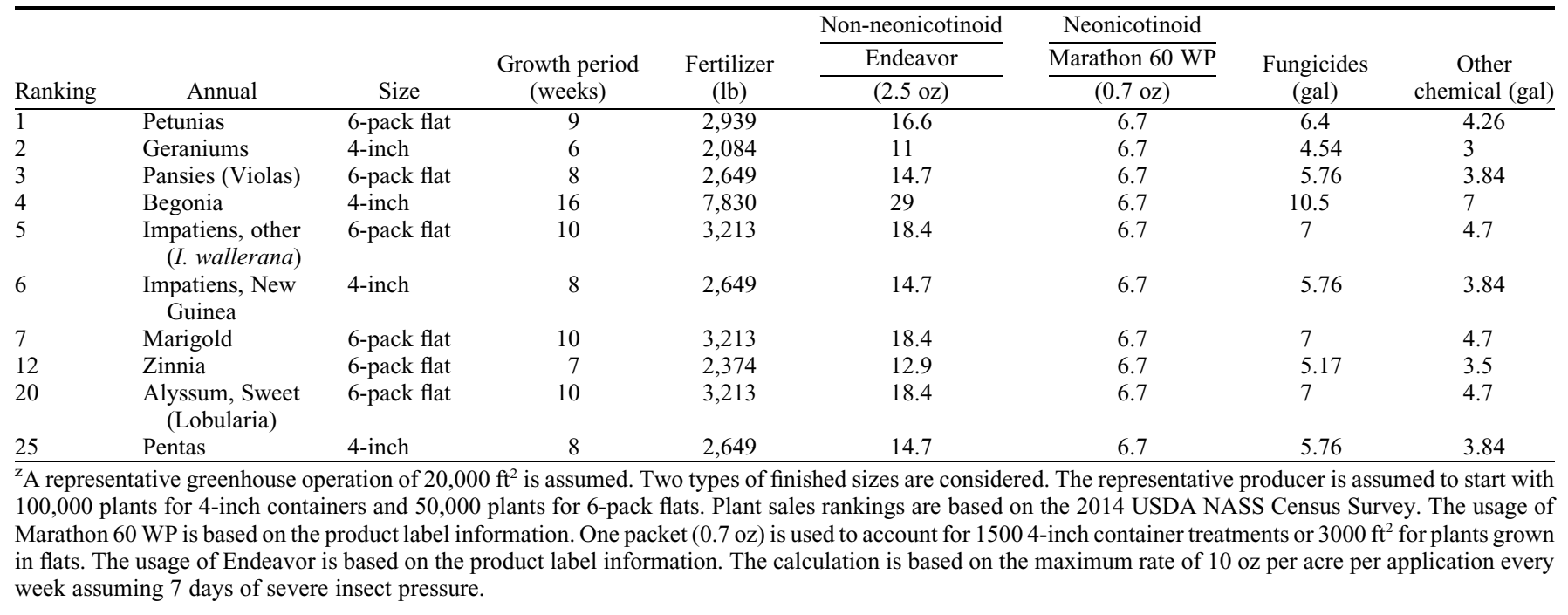

Table 2. Fertilizer and chemical usage for selected greenhouse-grown perennial plants. ${ }^{\mathrm{z}}$

\begin{tabular}{|c|c|c|c|c|c|c|c|c|}
\hline Ranking & Perennial plant & Size & $\begin{array}{c}\text { Growth } \\
\text { period (weeks) }\end{array}$ & $\begin{array}{l}\text { Fertilizer } \\
\text { (lb) }\end{array}$ & $\frac{\frac{\text { Non-neonicotinoid }}{\text { Endeavor }}}{(2.5 \mathrm{oz})}$ & $\frac{\frac{\text { Neonicotinoid }}{\text { Marathon } 60 \mathrm{WP}}}{(0.7 \mathrm{oz})}$ & $\begin{array}{l}\text { Fungicides } \\
\text { (gal) }\end{array}$ & $\begin{array}{c}\text { Other } \\
\text { chemical (gal) }\end{array}$ \\
\hline 1 & $\begin{array}{r}\text { Chrysanthemums } \\
\text { (hardy/garden) }\end{array}$ & 1 gallon & 16 & 4,897 & 29.44 & 7.0 & 10.66 & 7.1 \\
\hline 2 & Hostas & 1 gallon & 8 & 2,649 & 14.7 & 7.0 & 5.76 & 3.84 \\
\hline 3 & Daylilies & 1 gallon & 8 & 2,649 & 14.7 & 7.0 & 5.76 & 3.84 \\
\hline 5 & Salvia & 1 gallon & 24 & 7,143 & 40 & 7.0 & 15.56 & 10.4 \\
\hline 6 & Dianthus & 1 gallon & 26 & 7,698 & 40 & 7.0 & 16.75 & 11.2 \\
\hline 7 & $\begin{array}{l}\text { Coral bells } \\
\text { (Heuchera) }\end{array}$ & 1 gallon & 8 & 2,649 & 14.7 & 7.0 & 5.76 & 3.84 \\
\hline 11 & Echinacea & 1 gallon & 15 & 4,617 & 27.6 & 7.0 & 10 & 6.7 \\
\hline \multirow[t]{3}{*}{12} & Rudbeckia & 1 gallon & 32 & 9,391 & 40 & 7.0 & 20.44 & 13.6 \\
\hline & Nepeta $^{\mathrm{y}}$ & 1 gallon & 13 & 4,068 & 24 & 7.0 & 8.85 & 5.9 \\
\hline & Agastache $^{y}$ & 1 gallon & 15 & 4,617 & 27.6 & 7.0 & 10 & 6.7 \\
\hline
\end{tabular}

${ }^{\mathrm{z}}$ A representative greenhouse operation of $20,000 \mathrm{ft}^{2}$ starting with 50,000 plants was assumed. Rankings are from the 2014 USDA NASS Census Survey based on sales values. The usage of Marathon $60 \mathrm{WP}$ was based on the product label information. The standard application involved applying one packet $(0.7 \mathrm{oz})$ to treat 120-240 1-gallon containers. The total amount for 50,000 1-gallon plants using the standard application will exceed the maximum amount of 10.7 oz. per acre per year. Hence, the maximum amount of $10.7 \mathrm{oz}$ was applied in this analysis. The usage of Endeavor was based on the product label information. The calculation was based on the maximum rate of $10 \mathrm{oz}$ per acre per application every week assuming 7 days of severe insect pressure. For those exceeding the maximum of $100 \mathrm{oz}$ per acre per year, the maximum amount of $100 \mathrm{oz}$ per acre per year was used.

${ }^{\mathrm{y}}$ Plants not included in the NASS Survey.

periods used in this study can be used as reference points for producers to perform comparisons of their own production practices. Although Hinson et al. (2008) assumed a $5 \%$ loss for selected containergrown ornamental plants, Fisher et al. (2014) estimated the shrinkage rate across all plant types to be $\approx 8 \%$. Therefore, a $5 \%$ shrinkage rate is assumed for 4-inch containers and a $10 \%$ shrinkage rate is assumed for the sixpacks and 1-gallon containers to account for the proportion of total production loss when calculating sales revenue. The shrinkage rate partially captures yield uncertainty, which is not explicitly modeled in this analysis. In sensitivity analyses, the yield is kept constant to indicate that any switch of pest management practices will need to produce the same amount of yield to be comparable.

Direct costs. Eight detailed items were considered to capture the direct operating costs of a greenhouse. The direct cost cate- gories included seeds and plants, pots and containers, growing media, fertilizer, insecticides, fungicides, other chemical controls, and tags. Unit costs for materials were adopted from several published sources and individual interviews with growers. For example, unit prices for pots and containers and tags were adopted from a New Jersey greenhouse production analysis (Rutgers New Jersey Agricultural Experiment Station Farm Management, 2008). The cost of growing media was assumed to be $\$ 2.00$ per cubic foot (Fisher et al., 2014; Stathacos and White, 1981; UMass Extension Greenhouse Crops \& Floriculture Program, 2003). The prices for insecticides and other chemicals were based on retail prices obtained from vendors, but individual growers may receive discounts depending on the size of their transaction/ operation (i.e., bulk discounts). The total direct cost summarizes the costs of the eight detailed items mentioned. Details regarding calculating each cost component are presented in Table 3 using Chrysanthemum (perennial, 1 gallon) as an example; however, all other annual and perennial plants follow the same structure.

Labor costs. Specialty crop production is labor-intensive; therefore, a large portion of production costs is associated with labor. In this analysis, labor costs were calculated based on three broad categories: skilled managerial labor, unskilled labor, and pest control labor; hourly wage rates were set at $\$ 15.00, \$ 9.60$, and $\$ 12.00$, respectively. According to the Bureau of Labor Statistics, the national mean hourly wage for the green industry was $\$ 12.72$ in 2018 (NAICS Classification Code 45-2092, Farmworkers and Laborers, Crop, Nursery, and Greenhouse). Hinson et al. (2008) used $\$ 9.60$ and $\$ 15.30$ as wage rates to distinguish unskilled labor from skilled labor (e.g., tractor operators). 
Overhead costs. The third largest category in production costs is overhead costs. In this study, we separated overhead costs into heating and fuel costs and other overhead costs. Heating and fuel costs were calculated to cover the production area of $20,000 \mathrm{ft}^{2}$ throughout the production period and depended only on the lengths of the growth periods. Heating and fuel costs may vary depending on the location of the greenhouse. However, an analysis of this variation is beyond the scope of this study.

Economic performance indicators. The market prices used for calculating sales revenues for the 20 annual and perennial plants were based on combined USDA NASS data and wholesale price information received by growers (see Table 4 for more details). As previously mentioned, given the fierce competition within the green industry, it is legitimate to assume that individual growers are price takers. Net income (profit), gross margin, and profit margin were calculated for a representative grower to provide baseline

Table 3. Cost structure for hostas (perennial, 1 gallon): an example. ${ }^{z}$

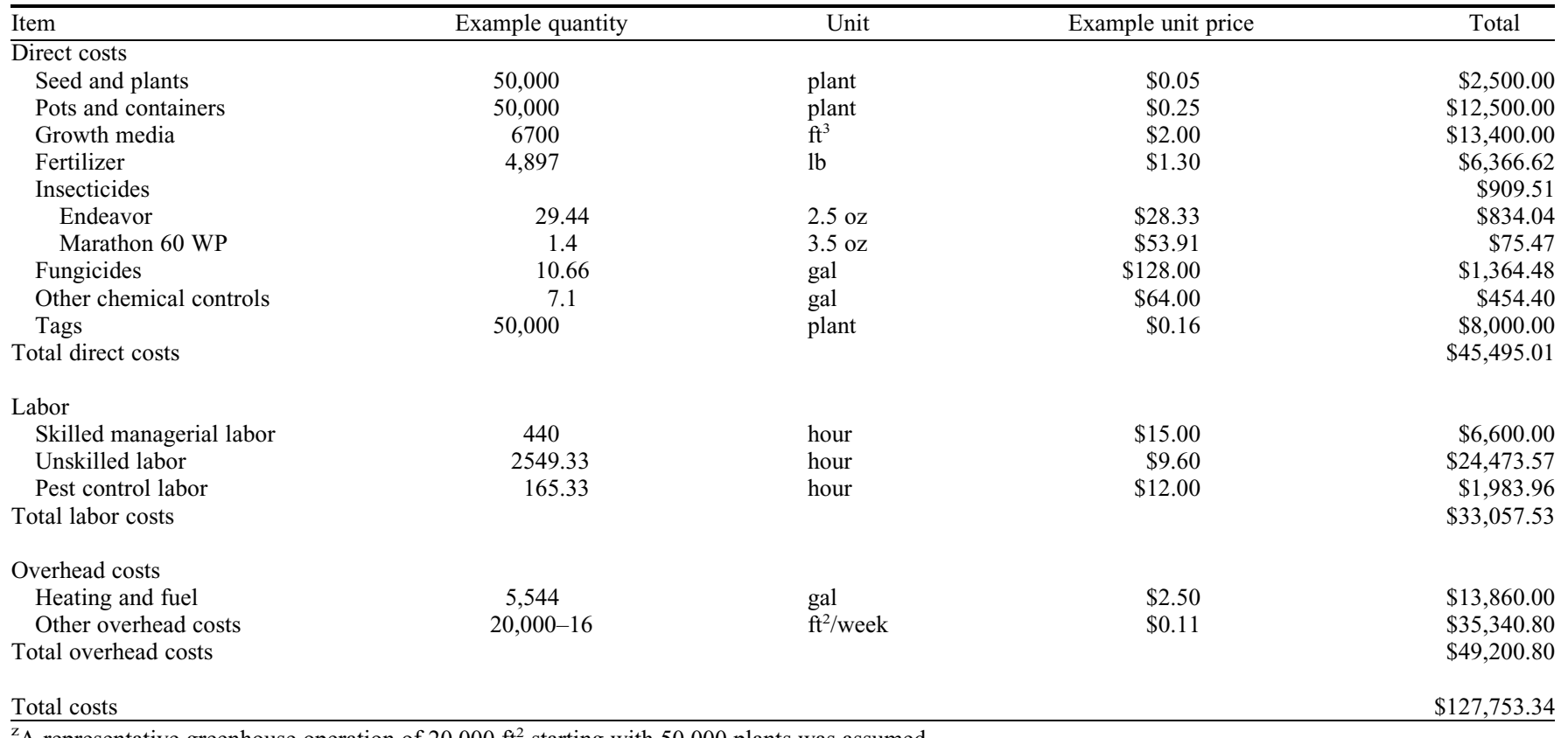

${ }^{\mathrm{z}} \mathrm{A}$ representative greenhouse operation of $20,000 \mathrm{ft}^{2}$ starting with 50,000 plants was assumed.

Table 4. Plant wholesale price.

\begin{tabular}{|c|c|c|c|c|c|c|}
\hline \multirow[b]{3}{*}{ Annual } & & & \multicolumn{4}{|c|}{ USDA wholesale price ${ }^{z}$ (dollars per unit) } \\
\hline & \multicolumn{2}{|c|}{ Price used in analysis (dollars per unit) } & \multicolumn{2}{|c|}{ In flat } & \multicolumn{2}{|c|}{ Less than 5-inch } \\
\hline & In flat & 4-inch & (2015) & (2018) & 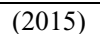 & (2018) \\
\hline$\overline{\text { Petunias }}$ & $\$ 8.76$ & - & $\$ 8.76$ & $\$ 9.62$ & $\$ 1.28$ & $\$ 1.30$ \\
\hline Pansies (Violas) & $\$ 8.91$ & - & $\$ 8.91$ & $\$ 9.72$ & $\$ 1.28$ & $\$ 1.30$ \\
\hline Begonia & - & $\$ 2.75$ & $\$ 8.33$ & $\$ 8.53$ & $\$ 1.05$ & $\$ 1.03$ \\
\hline Impatiens, other (I. wallerana) & $\$ 8.78$ & - & $\$ 8.78$ & $\$ 8.45$ & $\$ 1.00$ & $\$ 1.38$ \\
\hline Impatiens, New Guinea & - & $\$ 2.25$ & $\$ 9.76$ & $\$ 9.93$ & $\$ 1.52$ & $\$ 1.78$ \\
\hline Alyssum, Sweet (Lobularia) & $\$ 7.00$ & - & $\$ 8.87^{y}$ & $\$ 10.00^{y}$ & $\$ 1.38^{\mathrm{x}}$ & $\$ 1.45^{\mathrm{x}}$ \\
\hline \multirow[t]{2}{*}{ Pentas } & - & $\$ 1.20$ & $\$ 8.87^{y}$ & $\$ 10.00^{y}$ & $\$ 1.38^{\mathrm{x}}$ & $\$ 1.45^{\mathrm{x}}$ \\
\hline & & & \multicolumn{2}{|c|}{1 gallon up to 2 gallons } & \multicolumn{2}{|c|}{ 5-inch or larger } \\
\hline Perennial & \multicolumn{2}{|c|}{ 1-gallon } & $(2015)$ & $(2018)$ & (2015) & (2018) \\
\hline Chrysanthemums (hardy/garden) & \multicolumn{2}{|c|}{$\$ 5.00$} & - & - & $\$ 2.99$ & $\$ 3.34$ \\
\hline Echinacea & \multicolumn{2}{|c|}{$\$ 5.00$} & $\$ 4.01^{\mathrm{w}}$ & $\$ 4.06^{\mathrm{w}}$ & - & - \\
\hline Rudbeckia & \multirow{2}{*}{\multicolumn{2}{|c|}{$\$ 5.00$}} & $\$ 4.01^{\mathrm{w}}$ & $\$ 4.06^{\mathrm{w}}$ & - & - \\
\hline Nepeta & & & $\$ 4.01^{\mathrm{w}}$ & $\$ 4.06^{\mathrm{w}}$ & - & - \\
\hline Agastache & \multicolumn{2}{|c|}{$\$ 5.00$} & $\$ 4.01^{\mathrm{w}}$ & $\$ 4.06^{\mathrm{w}}$ & - & - \\
\hline
\end{tabular}

${ }^{\mathrm{z}}$ Wholesale prices are obtained from the USDA Floriculture Crops 2018 Summary (USDA NASS, 2019).

${ }^{\mathrm{y}}$ Prices are from the category of annual bedding/garden plants sold as flats, other flowering and foliar.

${ }^{x}$ Prices are from the category of annual bedding/garden plants sold in pots, other potted flowering and foliar plants.

${ }^{\mathrm{w}}$ Prices are from the category of herbaceous perennial plants sold in pots, other herbaceous perennials.

$-=$ not applicable, $\mathrm{NA}=$ not available. 
performance scenarios in the industry using the following formulas:

$$
\begin{aligned}
\text { Gross Margin }= & (\text { Total Sales } \\
& - \text { Total Direct Costs }) \\
& / \text { Total Sales }
\end{aligned}
$$

$$
\text { Net Income }=\text { Total Sales }- \text { Total Costs }
$$

\section{Profit Margin $=$ Net Income $/$ Total Sales}

where Total Sales was calculated as unit price $\times$ the number of plants $\times$ the shrinkage rate.
The gross margin measures the percentage of revenue that exceeds daily operating costs. Therefore, as an indicator of profitability, the higher the gross margin, the more efficient a given operation is in generating profit from operating costs involved in production. Because increases in total sales and revenue do not necessarily translate into increased profitability, it is necessary to introduce the net profit (in the absolute dollar amount) and net profit margin to measure profitability.

\section{Results}

Cost summary and economic performance. The total direct costs for the selected plants are summarized in Tables 5 and 6 . The total direct costs of producing annual and perennial plants are plant-specific and not necessarily higher for perennial plants and lower for annual plants. For example, the total direct costs of producing chrysanthemums and nepeta (with the lowest direct costs among the selected perennials) are less than $\$ 46,000$, which is lower than those of geraniums and pentas, which are the two annual plants with the lowest direct costs. Regarding high-cost plants, the total direct costs of producing hostas and coral bells significantly exceeded those of petunias and impatiens (I. wallerana).

In terms of detailed cost categories, the material costs, including seeds and plants, containers, and growing media, represent the largest portion of the total direct costs,

Table 5. Direct costs for selected greenhouse grown annual plants. ${ }^{z}$

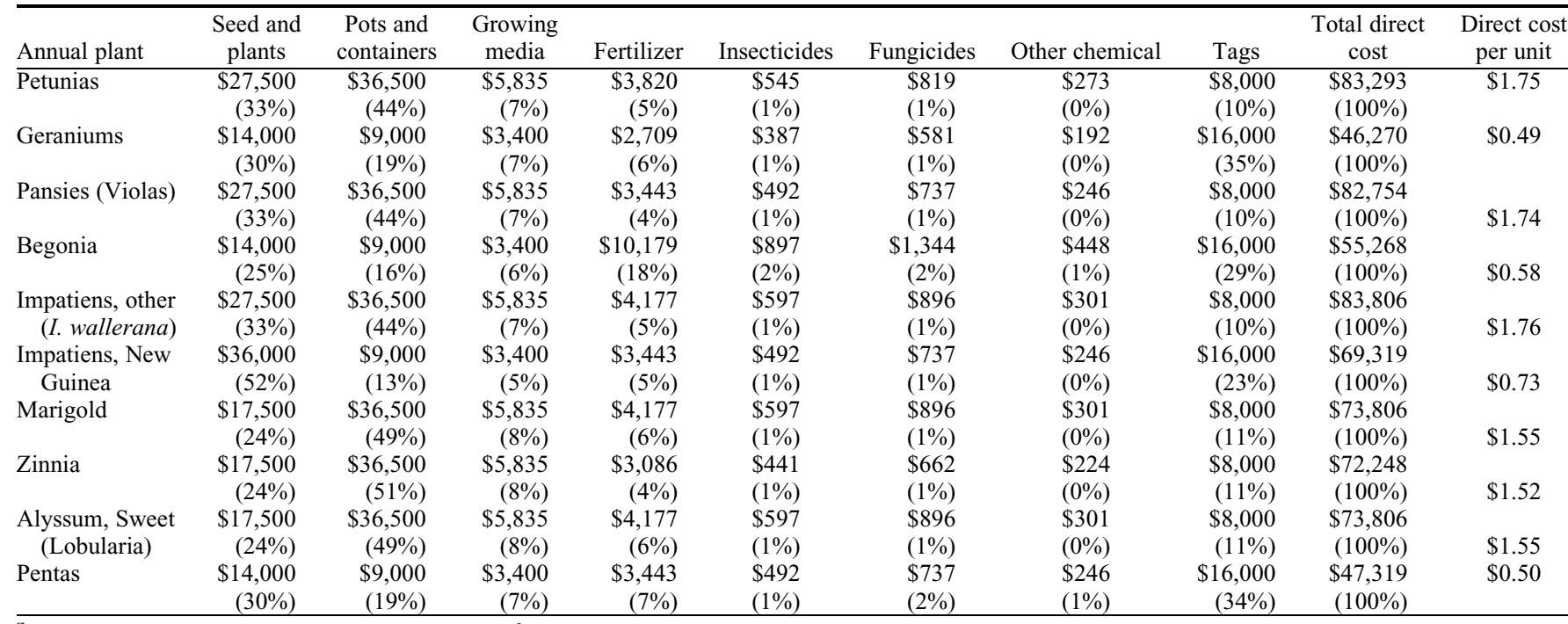

${ }^{\mathrm{z}} \mathrm{A}$ representative greenhouse operation of $20,000 \mathrm{ft}^{2}$ is assumed. Two types of finished sizes are considered. The representative producer is assumed to start with 100,000 plants for 4-inch containers and 50,000 plants for 6-pack flats. The growing media cost is calculated based on two fished sizes: 4-inch containers and flats.

\begin{tabular}{|c|c|c|c|c|c|c|c|c|c|c|}
\hline Perennial plant & $\begin{array}{l}\text { Seeds and } \\
\text { plants }\end{array}$ & $\begin{array}{l}\text { Pots and } \\
\text { containers }\end{array}$ & $\begin{array}{c}\text { Growing } \\
\text { media }\end{array}$ & Fertilizer & Insecticides & Fungicides & $\begin{array}{c}\text { Other } \\
\text { chemical }\end{array}$ & Tags & $\begin{array}{l}\text { Total direct } \\
\text { cost }\end{array}$ & $\begin{array}{l}\text { Direct cost } \\
\text { per unit }\end{array}$ \\
\hline Hostas & $\begin{array}{r}\$ 70,000 \\
(64 \%)\end{array}$ & $\begin{array}{r}\$ 12,500 \\
(11 \%)\end{array}$ & $\begin{array}{r}\$ 13,400 \\
(12 \%)\end{array}$ & $\begin{array}{r}\$ 3,444 \\
(3 \%)\end{array}$ & $\begin{array}{l}\$ 417 \\
(0 \%)\end{array}$ & $\begin{array}{l}\$ 737 \\
(1 \%)\end{array}$ & $\begin{array}{l}\$ 246 \\
(0 \%)\end{array}$ & $\begin{array}{r}\$ 8,000 \\
(7 \%)\end{array}$ & $\begin{array}{r}\$ 108,744 \\
(100 \%)\end{array}$ & $\$ 2.42$ \\
\hline Daylilies & $\begin{array}{r}\$ 43,000 \\
(53 \%)\end{array}$ & $\begin{array}{r}\$ 12,500 \\
(15 \%)\end{array}$ & $\begin{array}{r}\$ 13,400 \\
(16 \%)\end{array}$ & $\begin{array}{r}\$ 3,444 \\
(4 \%)\end{array}$ & $\begin{array}{l}\$ 492 \\
(1 \%)\end{array}$ & $\begin{array}{l}\$ 737 \\
(1 \%)\end{array}$ & $\begin{array}{l}\$ 245.76 \\
(0 \%)\end{array}$ & $\begin{array}{r}\$ 8,000 \\
(10 \%)\end{array}$ & $\begin{array}{r}\$ 81,819 \\
(100 \%)\end{array}$ & $\$ 1.82$ \\
\hline Salvia & $\begin{array}{r}\$ 6,500 \\
(12 \%)\end{array}$ & $\begin{array}{r}\$ 12,500 \\
(23 \%)\end{array}$ & $\begin{array}{r}\$ 13,400 \\
(25 \%)\end{array}$ & $\begin{array}{r}\$ 9,286 \\
(17 \%)\end{array}$ & $\begin{array}{r}\$ 1,209 \\
(2 \%)\end{array}$ & $\begin{array}{r}\$ 2,048 \\
(4 \%)\end{array}$ & $\begin{array}{l}\$ 685 \\
(1 \%)\end{array}$ & $\begin{array}{r}\$ 8,000 \\
(15 \%)\end{array}$ & $\begin{array}{r}\$ 53,627 \\
(100 \%)\end{array}$ & $\$ 1.19$ \\
\hline $\begin{array}{l}\text { Coral bells } \\
\text { (Heuchera) }\end{array}$ & $\begin{array}{r}\$ 85,000 \\
(69 \%)\end{array}$ & $\begin{array}{r}\$ 12,500 \\
(10 \%)\end{array}$ & $\begin{array}{r}\$ 13,400 \\
(11 \%)\end{array}$ & $\begin{array}{r}\$ 3,444 \\
(3 \%)\end{array}$ & $\begin{array}{l}\$ 492 \\
(0 \%)\end{array}$ & $\begin{array}{l}\$ 737 \\
(1 \%)\end{array}$ & $\begin{array}{l}\$ 246 \\
(0 \%)\end{array}$ & $\begin{array}{r}\$ 8,000 \\
(6 \%)\end{array}$ & $\begin{array}{r}\$ 123,819 \\
(100 \%)\end{array}$ & $\$ 2.75$ \\
\hline Echinacea & $\begin{array}{r}\$ 40,000 \\
(49 \%)\end{array}$ & $\begin{array}{r}\$ 12,500 \\
(15 \%)\end{array}$ & $\begin{array}{r}\$ 13,400 \\
(16 \%)\end{array}$ & $\begin{array}{r}\$ 6,002 \\
(7 \%)\end{array}$ & $\begin{array}{l}\$ 782 \\
(1 \%)\end{array}$ & $\begin{array}{r}\$ 1,280 \\
(2 \%)\end{array}$ & $\begin{array}{l}\$ 429 \\
(1 \%)\end{array}$ & $\begin{array}{r}\$ 8,000 \\
(10 \%)\end{array}$ & $\begin{array}{r}\$ 82,392 \\
(100 \%)\end{array}$ & $\$ 1.83$ \\
\hline Rudbeckia & $\begin{array}{r}\$ 6,500 \\
(11 \%)\end{array}$ & $\begin{array}{r}\$ 12,500 \\
(22 \%)\end{array}$ & $\begin{array}{r}\$ 13,400 \\
(23 \%)\end{array}$ & $\begin{array}{r}\$ 12,209 \\
(21 \%)\end{array}$ & $\begin{array}{r}\$ 1,209 \\
(2 \%)\end{array}$ & $\begin{array}{r}\$ 2,616 \\
(5 \%)\end{array}$ & $\begin{array}{l}\$ 870 \\
(2 \%)\end{array}$ & $\begin{array}{r}\$ 8,000 \\
(14 \%)\end{array}$ & $\begin{array}{r}\$ 57,304 \\
(100 \%)\end{array}$ & $\$ 1.27$ \\
\hline
\end{tabular}
Fertilizer and chemical usage are calculated based on and vary across growth periods only. The percentage of each direct cost category out of the total direct cost is reported in parentheses.

Table 6. Direct costs associated with selected greenhouse-grown perennial plants. ${ }^{2}$

${ }^{\mathrm{z}} \mathrm{A}$ representative greenhouse operation of $20,000 \mathrm{ft}^{2}$ starting with 50,000 plants was assumed. Growing media was calculated based on the size of a 1-gallon container. Fertilizer and chemical usage were calculated based on and vary across growth periods only.

${ }^{\mathrm{y}}$ Plants were not included in the NASS Survey. 
followed by tags and expenses for fertilizer. Material costs account for $50 \%$ to $80 \%$ of the total direct costs for the annual plants (Table 5) and $60 \%$ to $90 \%$ for perennial plants (Table 6). Annual plants, such as petunias, pansies, impatiens (other), marigold, zinnia, and sweet alyssum, and perennial plants, such as hostas, daylilies, coral bells, and echinacea, have relatively high material costs. More than $80 \%$ of the total direct costs are related to materials for these plants. Agrichemical costs in general are low. For example, insecticides alone only account for $\approx 1 \%$ of the direct costs for annual bedding plants and $2 \%$ for perennial plants.

Our calculations indicate that growers may face tradeoffs among material costs (e.g., seed costs and growing media) and fertilizer and chemical input costs depending on their decisions during the beginning stages of plants. For instance, production from seed germination may significantly reduce the amount spent for seeds compared with production from seedling plugs; however, this decision may inevitably increase costs related to growing media as well as fertilizer and chemical control costs resulting from a longer growth period. As a rule of thumb, growers should maintain a gross margin of $30 \%$ to $40 \%$ and a profit margin of $10 \%$ to $15 \%$ to be sustainable in the industry.

Detailed labor costs are summarized in Tables 7 and 8. Among 10 listed annual plants, geraniums (with a total labor cost of $\$ 12,397$ ) have the lowest labor costs and begonias (with a total labor cost of $\$ 33,058$ ) have the highest labor costs. The gap is much larger for perennial plants. For example, the total labor costs for rudbeckia is as high as $\$ 66,115$ and as low as $\$ 16,536$ for hostas and coral bells. Regardless of plant type, expenses for unskilled labor (e.g., picking and cutting) account for more than $70 \%$ of the total labor costs. The combined expenses for semi-skilled (e.g., pest control) and skilled (e.g., managerial) labor account for $20 \%$ to $30 \%$ of the total labor costs.

As shown in Tables 9 and 10, heating and fuel costs generally account for $30 \%$ to $40 \%$ of the overhead costs. Other overhead costs collectively describe expenses related to depreciation, interest, taxes, insurance, repair and maintenance, trucks and equipment, and other cash expenses, thus contributing $60 \%$ to $70 \%$ of the overhead costs. Because heating and fuel usage and other overhead costs are allocated across square footage and growth periods, plants with longer grower periods typically have higher overhead costs.

Total costs and economic performance indicators are summarized in Tables 11 and 12. Even though perennial plants in general have slightly higher production costs, all three economic indicators suggest that all annual and perennial plants generate positive economic returns. By simply looking at the gross margin, one may have the impression that the decision of whether to grow annual or perennial corps or which specific crop to grow may not be very important. However, high gross margins may not necessarily lead to high profit margins when labor costs are included because specialty crop production is labor-intensive. A cross-comparison between the gross margin and profit margin revealed more information regarding crop profitability. For example, among the top five annual plants (those with the largest sales values), geraniums have relatively low in gross margins and profit margins. Begonias have a high gross margin but are not as profitable as petunias and pansies. Even though gross margins for geraniums and pentas are similar, growing geraniums is much more profitable than growing pentas. For perennial plants, it is not surprising to see that the top three revenue-generating plants (i.e., chrysanthemums, hostas, and daylilies) have relatively high profit margins. By looking at the gross margin only, one might think hostas are not as profitable as salvia or dianthus, which have higher gross margins and much lower profit margins. However, producing rudbeckia and dianthus leads to extremely low profits and profit margins. Even though profit margins consider all of the related production costs and are a more reliable predictor of economic performance and profitability, our analysis indicated that examining multiple indicators

Table 7. Labor costs for selected greenhouse-grown annual plants. ${ }^{2}$

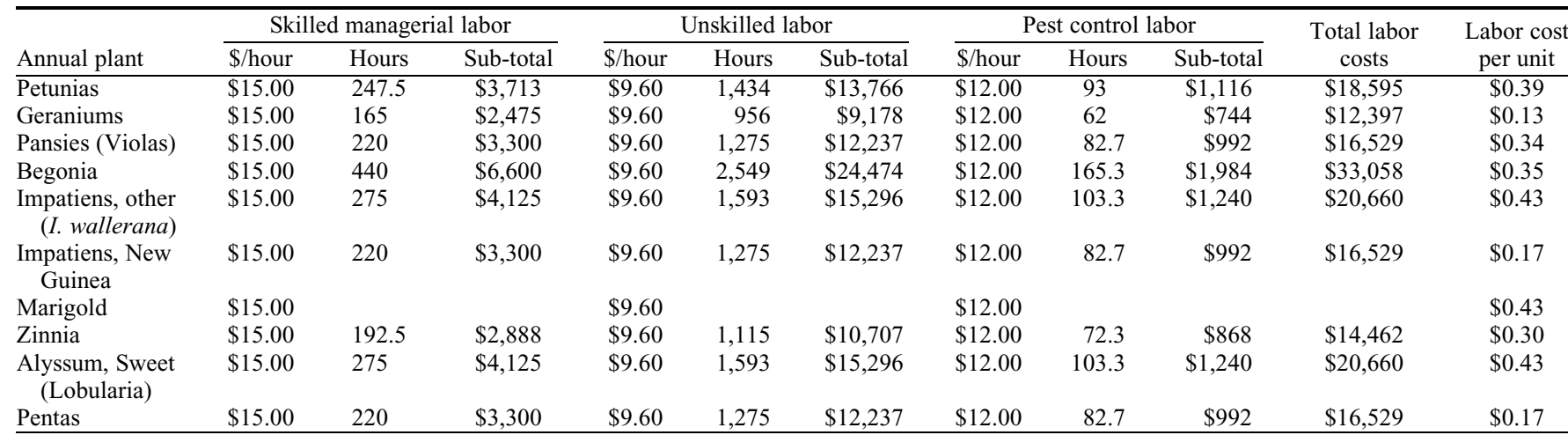

${ }^{\mathrm{z}} \mathrm{A}$ representative greenhouse operation of $20,000 \mathrm{ft}^{2}$ is assumed. Two types of finished sizes are considered. The representative producer is assumed to start with 100,000 plants for 4-inch containers and 50,000 for 6-pack flats. Labor hours are calculated based on and vary across growth periods only.

Table 8. Labor costs associated with selected greenhouse-grown perennial plants. ${ }^{z}$

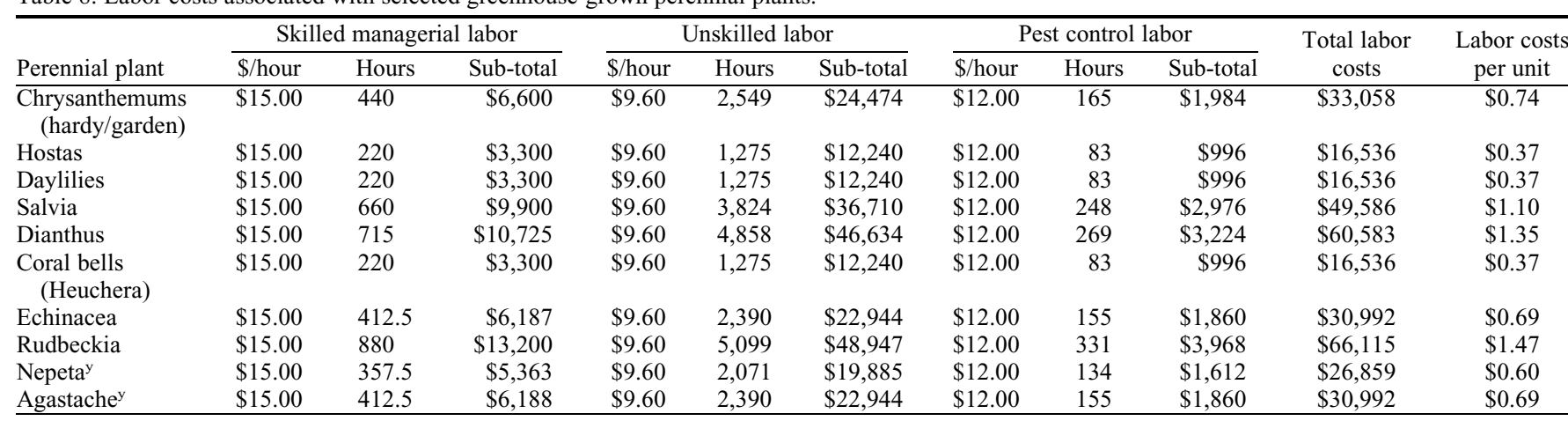

${ }^{\mathrm{z}} \mathrm{A}$ representative greenhouse operation of $20,000 \mathrm{ft}^{2}$ starting with 50,000 plants was assumed. Labor hours were calculated based on and vary across growth periods only.

${ }^{\mathrm{y}}$ Plants were not included in the NASS Survey. 
is more informative for growers when making crop choice decisions. Profitability varies significantly across the different plants. This is particularly true for perennial plant production, which may involve more uncertainties (e.g., pest pressure) due to longer growth periods. Remember, it is recommended that growers maintain a gross margin of $30 \%$ to $40 \%$ and a profit margin of $10 \%$ to $15 \%$ to be sustainable in the industry.

Sensitivity analysis. In response to the increased attention to policies related to pollinator health (Gemmill-Herren, 2016) and consumer valuation for pollinator-friendly labels (Khachatryan et al., 2017), we considered profit margin scenarios related to cost changes induced by alternative production practices, such as pesticide-free or neonicotinoid-free practices. Tables 13 and 14 present the uncertainty associated with total labor costs varying between $-20 \%$ and $+30 \%$ (Supplemental Fig. 1). The scenario was set to be unbalanced due to anticipated increases in labor costs associated with alternative pest management practices that may require more labor inputs associated with all types of labors. For instance, switching from chemical control to IPM may involve not only pest control labor scouting for pests or additional applications of pesticides but also managerial labor for monitoring disease and coordinating among staff members as well as unskilled labor (e.g., for hand weeding, watering, etc.). In addition, previous research comparing production costs between organic and conventional production systems showed that production costs for organic products tend to be higher (Brumfield and Brennan, 1996; Butler, 2002; Takele et al., 2007) or at least similar to those for conventional products (Barham et al., 2006; Dalton et al., 2005, 2008). Tables 15 and 16 demonstrate the profit margins with potential changes in chemical usage ranging from $-100 \%$ to $+100 \%$ (Supplemental Fig. 2). This calculation simulates two possible production regimes that greenhouse growers could adopt: either switch to a completely chemical-free program or intensively substitute neonicotinoid insecticides with other chemical controls, depending on their risk perceptions, financial capabilities, equipment, and infrastructure.

Compared to chemical control costs, labor cost is the dominant factor affecting profit margins. A change in pest management practices such as pest application frequency might significantly increase or decrease labor input requirements, thus significantly affecting greenhouse growers' profitability. Furthermore, a switch in pest management practices such as incorporating IPM into production may involve increased costs not only in unskilled labor but also in skilled managerial and pest control labor. Our anal- ysis shows that profit margins were not significantly affected by changes in agrichemical inputs due to their small share in total production costs. This finding is consistent with that of Fisher et al. (2014), who also indicated that lowering costs of pesticides or fertilizers alone has little impact on profitability. The combined effects of chemical and labor inputs induced by a switch in chemical use or pest management practices have a more profound impact on growers' profitability and profit margins. Therefore, we recommend that growers should emphasize labor item shifts and associated changes in costs when considering potential cost savings.

\section{Conclusions}

This article summarizes a partial enterprise budgeting analysis conducted for 20 popular annual bedding and perennial plants based on the USDA rankings of sales values. The budget represents an operation of a $20,000-\mathrm{ft}^{2}$ greenhouse and serves as an economic benchmark for growers with operations of comparable sizes and characteristics. By knowing details about the costs involved in the production process, producers can focus on cost reduction techniques in specific areas and maintain low-cost, competitive production practices (e.g., lean processing). Although producing a set of ornamental

Table 9. Overhead costs associated with selected greenhouse-grown annual bedding plants. ${ }^{\mathrm{z}}$

\begin{tabular}{|c|c|c|c|c|c|c|c|c|}
\hline \multirow[b]{2}{*}{ Annual plant } & \multicolumn{3}{|c|}{ Heating and fuel } & \multicolumn{3}{|c|}{ Other overhead costs } & \multirow{2}{*}{$\begin{array}{l}\text { Total overhead } \\
\text { costs }\end{array}$} & \multirow{2}{*}{$\begin{array}{l}\text { Overhead costs } \\
\text { per unit }\end{array}$} \\
\hline & \$/gallon & Gallon & Sub-total & $\overline{\$ / \mathrm{ft}^{2} / \text { week }}$ & $\mathrm{ft}^{2} /$ week & Sub-total & & \\
\hline Geraniums & $\$ 2.50$ & 2,079 & $\$ 5,196$ & $\$ 0.11$ & $20,000 \times 6$ & $\$ 13,253$ & $\$ 18,449$ & $\$ 0.20$ \\
\hline Pansies (Violas) & $\$ 2.50$ & 2,772 & $\$ 6,930$ & $\$ 0.11$ & $20,000 \times 8$ & $\$ 17,670$ & $\$ 24,600$ & $\$ 0.52$ \\
\hline $\begin{array}{r}\text { Impatiens, other } \\
\text { (I. wallerana })\end{array}$ & $\$ 2.50$ & 3,465 & $\$ 8,663$ & $\$ 0.11$ & $20,000 \times 10$ & $\$ 22,088$ & $\$ 30,751$ & $\$ 0.65$ \\
\hline $\begin{array}{l}\text { Impatiens, New } \\
\text { Guinea }\end{array}$ & $\$ 2.50$ & 2,772 & $\$ 6,930$ & $\$ 0.11$ & $20,000 \times 8$ & $\$ 17,670$ & $\$ 24,600$ & $\$ 0.26$ \\
\hline Zinnia & $\$ 2.50$ & 2,426 & $\$ 6,064$ & $\$ 0.11$ & $20,000 \times 7$ & $\$ 15,462$ & $\$ 21,525$ & $\$ 0.45$ \\
\hline $\begin{array}{c}\text { Alyssum, Sweet } \\
\text { (Lobularia) }\end{array}$ & $\$ 2.50$ & 3,465 & $\$ 8,663$ & $\$ 0.11$ & $20,000 \times 10$ & $\$ 22,088$ & $\$ 30,751$ & $\$ 0.65$ \\
\hline Pentas & $\$ 2.50$ & 2,772 & $\$ 6,930$ & $\$ 0.11$ & $20,000 \times 8$ & $\$ 17,670$ & $\$ 24,600$ & $\$ 0.26$ \\
\hline
\end{tabular}

${ }^{\mathrm{z}} \mathrm{A}$ representative greenhouse operation of $20,000 \mathrm{ft}^{2}$ is assumed. Two types of finished sizes are considered. The representative producer is assumed to start with 100,000 plants for 4-inch containers and 50,000 for 6-pack flats. Heating and fuel usage are calculated based on growth periods only. Other overhead costs include depreciation, interest, taxes, insurance, repair and maintenance, truck and equipment, and other cash expenses.

Table 10. Overhead costs associated with selected greenhouse-grown perennial plants. ${ }^{2}$

\begin{tabular}{|c|c|c|c|c|c|c|c|c|}
\hline \multirow[b]{2}{*}{ Perennial plant } & \multicolumn{3}{|c|}{ Heating and fuel } & \multicolumn{3}{|c|}{ Other overhead costs } & \multirow{2}{*}{$\begin{array}{c}\text { Total overhead } \\
\text { costs }\end{array}$} & \multirow{2}{*}{$\begin{array}{l}\text { Overhead costs } \\
\text { per unit }\end{array}$} \\
\hline & \$/gallon & Gallon & Sub-total & $\$ / \mathrm{ft}^{2} /$ week & $\mathrm{ft}^{2} /$ week & Sub-total & & \\
\hline $\begin{array}{l}\text { Chrysanthemums } \\
\text { (hardy/garden) }\end{array}$ & $\$ 2.50$ & 5,544 & $\$ 13,860$ & $\$ 0.11$ & $20,000 \times 16$ & $\$ 35,341$ & $\$ 49,201$ & $\$ 1.09$ \\
\hline Hostas & $\$ 2.50$ & 2,772 & $\$ 6,930$ & $\$ 0.11$ & $20,000 \times 8$ & $\$ 17,670$ & $\$ 24,600$ & $\$ 0.55$ \\
\hline Daylilies & $\$ 2.50$ & 2,772 & $\$ 6,930$ & $\$ 0.11$ & $20,000 \times 8$ & $\$ 17,670$ & $\$ 24,600$ & $\$ 0.55$ \\
\hline Salvia & $\$ 2.50$ & 8,316 & $\$ 20,790$ & $\$ 0.11$ & $20,000 \times 24$ & $\$ 53,011$ & $\$ 73,801$ & $\$ 1.64$ \\
\hline Dianthus & $\$ 2.50$ & 8,996 & $\$ 22,490$ & $\$ 0.11$ & $20,000 \times 26$ & $\$ 57,429$ & $\$ 79,919$ & $\$ 1.78$ \\
\hline $\begin{array}{l}\text { Coral bells } \\
\text { (Heuchera) }\end{array}$ & $\$ 2.50$ & 2,772 & $\$ 6,930$ & $\$ 0.11$ & $20,000 \times 8$ & $\$ 17,670$ & $\$ 46,126$ & $\$ 0.55$ \\
\hline Echinacea & $\$ 2.50$ & 5,198 & $\$ 12,994$ & $\$ 0.11$ & $20,000 \times 15$ & $\$ 33,132$ & $\$ 30,751$ & $\$ 1.03$ \\
\hline Rudbeckia & $\$ 2.50$ & 11,088 & $\$ 27,720$ & $\$ 0.11$ & $20,000 \times 32$ & $\$ 70,682$ & $\$ 98,402$ & $\$ 2.19$ \\
\hline Nepeta $^{\mathrm{y}}$ & $\$ 2.50$ & 4,505 & $\$ 11,261$ & $\$ 0.11$ & $20,000 \times 13$ & $\$ 28,714$ & $\$ 39,976$ & $\$ 0.89$ \\
\hline Agastache $^{y}$ & $\$ 2.50$ & 5,198 & $\$ 12,994$ & $\$ 0.11$ & $20,000 \times 15$ & $\$ 33,132$ & $\$ 46,126$ & $\$ 1.03$ \\
\hline
\end{tabular}

${ }_{\mathrm{z}}^{\mathrm{A}}$ representative greenhouse operation of $20,000 \mathrm{ft}^{2}$ starting with 50,000 plants was assumed. Heating and fuel usage were calculated based on growth periods only. Other overhead costs include depreciation, interest, taxes, insurance, repair and maintenance, truck and equipment, and other cash expenses.

${ }^{\mathrm{y}}$ Plants were not included in the NASS Survey. 


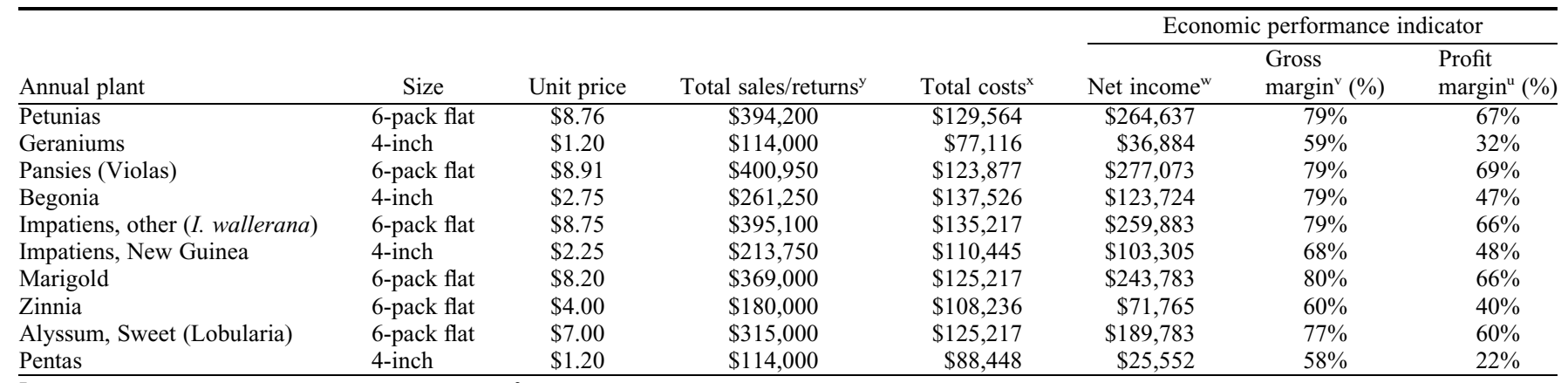

${ }^{\mathrm{z}} \mathrm{A}$ representative greenhouse operation of $20,000 \mathrm{ft}^{2}$ is assumed. Two types of finished sizes are considered. The representative producer is assumed to start with 100,000 plants for 4-inch containers and 50,000 for 6-pack flats. A shrinkage rate of 5\% is assumed for 4-inch containers and that of $10 \%$ is assumed for flats to cover the proportion of total production loss. Unit price is the price per container for 4-inch containers and price per flat for 6-pack flats.

${ }^{\mathrm{y}}$ Total sales/returns $=$ unit price $\times$ no. of plants $\times$ shrinkage rate.

${ }^{\mathrm{x}}$ Total costs sum up the direct costs, labor costs and overhead costs.

${ }^{\mathrm{w}} \mathrm{Net}$ income $=$ total sales - total costs.

${ }^{\mathrm{v}}$ Gross margin $=($ total sales - direct costs $) /$ total sales.

urofit margin $=$ net income $/$ total sales.

Table 12. Economic performance indicators for selected perennial plants. ${ }^{2}$

\begin{tabular}{|c|c|c|c|c|c|c|c|}
\hline \multirow[b]{2}{*}{ Perennial plant } & \multirow[b]{2}{*}{ Size } & \multirow[b]{2}{*}{ Unit price } & \multirow[b]{2}{*}{ Total sales/returns ${ }^{\mathrm{y}}$} & \multirow[b]{2}{*}{ Total costs ${ }^{x}$} & \multicolumn{3}{|c|}{ Economic performance indicator } \\
\hline & & & & & Net income ${ }^{\mathrm{w}}$ & $\begin{array}{c}\text { Gross } \\
\operatorname{margin}^{v}(\%)\end{array}$ & $\begin{array}{c}\text { Profit } \\
\text { margin }^{\mathrm{u}}(\%)\end{array}$ \\
\hline $\begin{array}{r}\text { Chrysanthemums } \\
\text { (hardy/garden) }\end{array}$ & 1-gallon & $\$ 5.00$ & $\$ 225,000$ & $\$ 127,753$ & $\$ 97,247$ & $80 \%$ & $43 \%$ \\
\hline Hostas & 1-gallon & $\$ 5.00$ & $\$ 225,000$ & $\$ 149,880$ & $\$ 75,120$ & $52 \%$ & $33 \%$ \\
\hline Daylilies & 1-gallon & $\$ 5.00$ & $\$ 225,000$ & $\$ 122,955$ & $\$ 102,045$ & $64 \%$ & $45 \%$ \\
\hline Salvia & 1-gallon & $\$ 5.00$ & $\$ 225,000$ & $\$ 177,015$ & $\$ 47,985$ & $76 \%$ & $21 \%$ \\
\hline Dianthus & 1-gallon & $\$ 5.00$ & $\$ 225,000$ & $\$ 194,978$ & $\$ 30,022$ & $76 \%$ & $13 \%$ \\
\hline Echinacea & 1-gallon & $\$ 5.00$ & $\$ 225,000$ & $\$ 159,510$ & $\$ 65,490$ & $63 \%$ & $29 \%$ \\
\hline Rudbeckia & 1-gallon & $\$ 5.00$ & $\$ 225,000$ & $\$ 221,821$ & $\$ 3,179$ & $75 \%$ & $1 \%$ \\
\hline Nepeta $^{t}$ & 1-gallon & $\$ 5.00$ & $\$ 225,000$ & $\$ 112,789$ & $\$ 112,211$ & $80 \%$ & $50 \%$ \\
\hline Agastache $^{t}$ & 1-gallon & $\$ 5.00$ & $\$ 225,000$ & $\$ 123,510$ & $\$ 101,490$ & $79 \%$ & $45 \%$ \\
\hline
\end{tabular}

${ }^{\mathrm{z}} \mathrm{A}$ representative greenhouse operation of $20,000 \mathrm{ft}^{2}$ starting with 50,000 plants was assumed. Shrinkage of $10 \%$ was assumed to cover the proportion of total production loss.

${ }^{\mathrm{y}}$ Total sales/returns $=$ unit price $\times$ no. of plants $\times$ shrinkage rate.

${ }^{\mathrm{x}}$ Total costs sum up the direct costs, labor costs, and overhead costs.

${ }^{\mathrm{w}} \mathrm{Net}$ income $=$ total sales - total costs.

${ }^{\mathrm{v}}$ Gross margin $=($ total sales - direct costs $) /$ total sales.

urofit margin $=$ net income $/$ total sales.

${ }^{\text {t}}$ Plants were not included in the NASS Survey.

Table 13. Profit margin scenarios with uncertainty in labor cost. ${ }^{\mathrm{z}}$

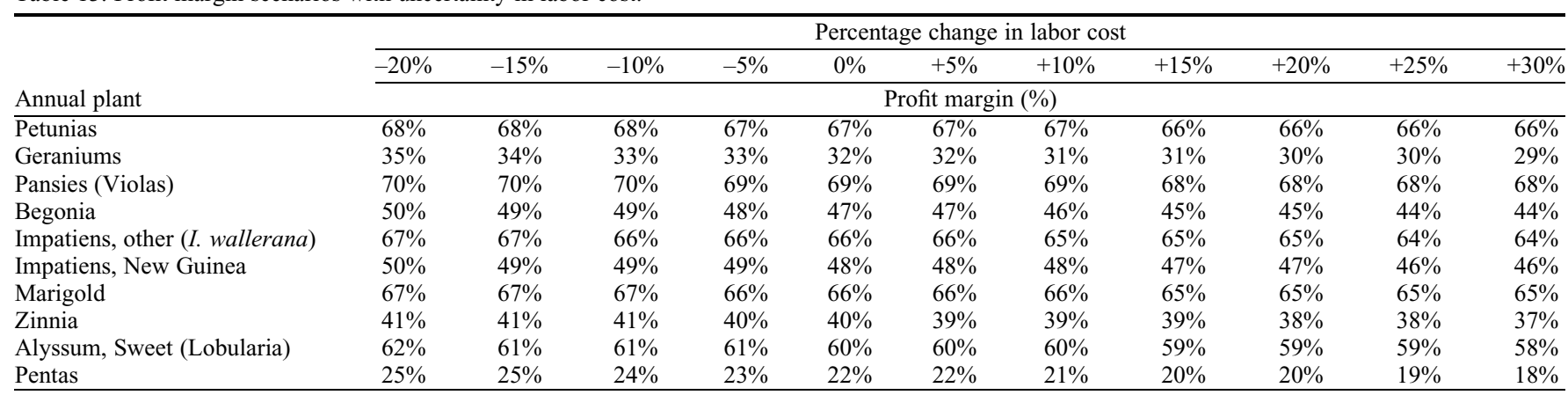

${ }^{\mathrm{z}} \mathrm{A}$ representative greenhouse operation of $20,000 \mathrm{ft}^{2}$ is assumed. Two types of finished sizes are considered. The representative producer is assumed to start with 100,000 plants for 4-inch containers and 50,000 for 6-pack flats. Profit margin = net income / total sales. Sensitivity analysis is based on varying labor costs within a range of $-20 \%$ to $+30 \%$ at an increment of $5 \%$. Other results were excluded in the table.

crops rather than a single crop is more common in the green industry, enterprise budget estimates for each individual crop are still useful for identifying which crop might be more profitable. Depending on the size of the operation, as well as the combination of crops produced, production costs might vary significantly among growers. This feature was partially captured by our sensitivity analysis by varying input costs considering an average grower operating a greenhouse with a production area of $100,000 \mathrm{ft}^{2}$ producing a crop mix of five to six crops. A straightforward application of our analysis involved aggregating a few different combinations of crops from our list. Based on our analysis, a grower producing the top five profitable crops (i.e., petunia, pansies, marigold, daylilies, and nepeta) would be more profitable than a grower producing a combination of the least five profitable crops 


\begin{tabular}{|c|c|c|c|c|c|c|c|c|c|c|c|}
\hline \multirow[b]{3}{*}{ Perennial plant } & \multicolumn{11}{|c|}{ Percentage change in labor cost } \\
\hline & $-20 \%$ & $-15 \%$ & $-10 \%$ & $-5 \%$ & $0 \%$ & $+5 \%$ & $+10 \%$ & $+15 \%$ & $+20 \%$ & $+25 \%$ & $+30 \%$ \\
\hline & \multicolumn{11}{|c|}{ Profit margin (\%) } \\
\hline Chrysanthemums (hardy/garden) & $46 \%$ & $45 \%$ & $45 \%$ & $44 \%$ & $43 \%$ & $42 \%$ & $42 \%$ & $41 \%$ & $40 \%$ & $40 \%$ & $39 \%$ \\
\hline Hostas & $35 \%$ & $34 \%$ & $34 \%$ & $34 \%$ & $33 \%$ & $33 \%$ & $33 \%$ & $32 \%$ & $32 \%$ & $32 \%$ & $31 \%$ \\
\hline Daylilies & $47 \%$ & $46 \%$ & $46 \%$ & $46 \%$ & $45 \%$ & $45 \%$ & $45 \%$ & $44 \%$ & $44 \%$ & $44 \%$ & $43 \%$ \\
\hline Salvia & $26 \%$ & $25 \%$ & $24 \%$ & $22 \%$ & $21 \%$ & $20 \%$ & $19 \%$ & $18 \%$ & $17 \%$ & $16 \%$ & $15 \%$ \\
\hline Dianthus & $19 \%$ & $17 \%$ & $16 \%$ & $15 \%$ & $13 \%$ & $12 \%$ & $11 \%$ & $9 \%$ & $8 \%$ & $7 \%$ & $5 \%$ \\
\hline Coral bells (Heuchera) & $28 \%$ & $28 \%$ & $27 \%$ & $27 \%$ & $27 \%$ & $26 \%$ & $26 \%$ & $26 \%$ & $25 \%$ & $25 \%$ & $24 \%$ \\
\hline Echinacea & $32 \%$ & $31 \%$ & $30 \%$ & $30 \%$ & $29 \%$ & $28 \%$ & $28 \%$ & $27 \%$ & $26 \%$ & $26 \%$ & $25 \%$ \\
\hline Rudbeckia & $7 \%$ & $6 \%$ & $4 \%$ & $3 \%$ & $1 \%$ & $0 \%$ & $-2 \%$ & $-3 \%$ & $-4 \%$ & $-6 \%$ & $-7 \%$ \\
\hline Nepeta $^{y}$ & $58 \%$ & $57 \%$ & $57 \%$ & $56 \%$ & $56 \%$ & $55 \%$ & $55 \%$ & $54 \%$ & $53 \%$ & $53 \%$ & $52 \%$ \\
\hline Agastache $^{y}$ & $48 \%$ & $47 \%$ & $46 \%$ & $46 \%$ & $45 \%$ & $44 \%$ & $44 \%$ & $43 \%$ & $42 \%$ & $42 \%$ & $41 \%$ \\
\hline
\end{tabular}

${ }^{\mathrm{z}}$ A representative greenhouse operation of $20,000 \mathrm{ft}^{2}$ starting with 50,000 plants is assumed. Profit margin $=$ net income $/$ total sales. Sensitivity analysis was based on varying labor costs within a range of $-20 \%$ to $+30 \%$ at an increment of $5 \%$. Other results were excluded from the table.

${ }^{\mathrm{y}}$ Plants were not included in the NASS Survey.

Table 15. Profit margin scenarios with uncertainty in agrichemical costs. ${ }^{\mathrm{z}}$

\begin{tabular}{|c|c|c|c|c|c|c|c|c|c|c|c|}
\hline \multirow[b]{3}{*}{ Annual plant } & \multicolumn{11}{|c|}{ Percentage change in agrichemical costs } \\
\hline & $-100 \%$ & $-75 \%$ & $-50 \%$ & $-25 \%$ & $-10 \%$ & $0 \%$ & $10 \%$ & $+25 \%$ & $+50 \%$ & $+75 \%$ & $+100 \%$ \\
\hline & \multicolumn{11}{|c|}{ Profit margin (\%) } \\
\hline$\overline{\text { Petunias }}$ & $68 \%$ & $67 \%$ & $67 \%$ & $67 \%$ & $67 \%$ & $67 \%$ & $67 \%$ & $67 \%$ & $67 \%$ & $67 \%$ & $67 \%$ \\
\hline Geraniums & $33 \%$ & $33 \%$ & $33 \%$ & $33 \%$ & $32 \%$ & $32 \%$ & $32 \%$ & $32 \%$ & $32 \%$ & $32 \%$ & $31 \%$ \\
\hline Pansies (Violas) & $69 \%$ & $69 \%$ & $69 \%$ & $69 \%$ & $69 \%$ & $69 \%$ & $69 \%$ & $69 \%$ & $69 \%$ & $69 \%$ & $69 \%$ \\
\hline Begonia & $48 \%$ & $48 \%$ & $48 \%$ & $48 \%$ & $47 \%$ & $47 \%$ & $47 \%$ & $47 \%$ & $47 \%$ & $47 \%$ & $46 \%$ \\
\hline Impatiens, other (I. wallerana) & $66 \%$ & $66 \%$ & $66 \%$ & $66 \%$ & $66 \%$ & $66 \%$ & $66 \%$ & $66 \%$ & $66 \%$ & $65 \%$ & $65 \%$ \\
\hline Impatiens, New Guinea & $49 \%$ & $49 \%$ & $49 \%$ & $49 \%$ & $48 \%$ & $48 \%$ & $48 \%$ & $48 \%$ & $48 \%$ & $48 \%$ & $48 \%$ \\
\hline Marigold & $67 \%$ & $66 \%$ & $66 \%$ & $66 \%$ & $66 \%$ & $66 \%$ & $66 \%$ & $66 \%$ & $66 \%$ & $66 \%$ & $66 \%$ \\
\hline Zinnia & $41 \%$ & $40 \%$ & $40 \%$ & $40 \%$ & $40 \%$ & $40 \%$ & $40 \%$ & $40 \%$ & $40 \%$ & $40 \%$ & $40 \%$ \\
\hline Alyssum, Sweet (Lobularia) & $61 \%$ & $61 \%$ & $61 \%$ & $60 \%$ & $60 \%$ & $60 \%$ & $60 \%$ & $60 \%$ & $60 \%$ & $60 \%$ & $60 \%$ \\
\hline Pentas & $24 \%$ & $23 \%$ & $23 \%$ & $23 \%$ & $23 \%$ & $22 \%$ & $22 \%$ & $22 \%$ & $21 \%$ & $21 \%$ & $21 \%$ \\
\hline
\end{tabular}


100,000 plants for 4 -inch containers and 50,000 for 6-pack flats. Profit margin $=$ net income / total sales. Sensitivity analysis is based on varying chemical control costs within a range of $-100 \%$ to $+100 \%$ at an increment of $5 \%$. Other results are excluded from the table.

Table 16. Profit margin scenarios with uncertainty in agrichemical costs. ${ }^{2}$

\begin{tabular}{|c|c|c|c|c|c|c|c|c|c|c|c|}
\hline \multirow[b]{3}{*}{ Perennial plant } & \multicolumn{11}{|c|}{ Percentage change in agrichemical costs } \\
\hline & $-100 \%$ & $-75 \%$ & $-50 \%$ & $-25 \%$ & $-10 \%$ & $0 \%$ & $10 \%$ & $+25 \%$ & $+50 \%$ & $+75 \%$ & $+100 \%$ \\
\hline & \multicolumn{11}{|c|}{ Profit margin $(\%)$} \\
\hline Chrysanthemums (hardy/garden) & $44 \%$ & $44 \%$ & $44 \%$ & $44 \%$ & $43 \%$ & $43 \%$ & $43 \%$ & $43 \%$ & $43 \%$ & $42 \%$ & $42 \%$ \\
\hline Hostas & $34 \%$ & $34 \%$ & $34 \%$ & $34 \%$ & $34 \%$ & $34 \%$ & $34 \%$ & $33 \%$ & $33 \%$ & $33 \%$ & $33 \%$ \\
\hline Daylilies & $46 \%$ & $46 \%$ & $46 \%$ & $46 \%$ & $45 \%$ & $45 \%$ & $45 \%$ & $45 \%$ & $45 \%$ & $45 \%$ & $45 \%$ \\
\hline Salvia & $23 \%$ & $23 \%$ & $22 \%$ & $22 \%$ & $22 \%$ & $21 \%$ & $21 \%$ & $21 \%$ & $20 \%$ & $20 \%$ & $20 \%$ \\
\hline Dianthus & $15 \%$ & $15 \%$ & $15 \%$ & $14 \%$ & $14 \%$ & $13 \%$ & $13 \%$ & $13 \%$ & $12 \%$ & $12 \%$ & $12 \%$ \\
\hline Coral bells (Heuchera) & $27 \%$ & $27 \%$ & $27 \%$ & $27 \%$ & $27 \%$ & $27 \%$ & $27 \%$ & $27 \%$ & $26 \%$ & $26 \%$ & $26 \%$ \\
\hline Echinacea & $30 \%$ & $30 \%$ & $30 \%$ & $30 \%$ & $30 \%$ & $29 \%$ & $29 \%$ & $29 \%$ & $29 \%$ & $29 \%$ & $29 \%$ \\
\hline Rudbeckia & $3 \%$ & $3 \%$ & $2 \%$ & $2 \%$ & $2 \%$ & $1 \%$ & $1 \%$ & $1 \%$ & $0 \%$ & $0 \%$ & $-1 \%$ \\
\hline Nepeta $^{\mathrm{y}}$ & $51 \%$ & $51 \%$ & $50 \%$ & $50 \%$ & $50 \%$ & $50 \%$ & $50 \%$ & $50 \%$ & $49 \%$ & $49 \%$ & $49 \%$ \\
\hline Agastache $^{\mathrm{y}}$ & $46 \%$ & $46 \%$ & $46 \%$ & $45 \%$ & $45 \%$ & $45 \%$ & $45 \%$ & $45 \%$ & $45 \%$ & $44 \%$ & $44 \%$ \\
\hline
\end{tabular}

${ }^{\mathrm{z}}$ A representative greenhouse operation of 20,000 $\mathrm{ft}^{2}$ starting with 50,000 plants was assumed. Profit margin $=$ net income / total sales. Sensitivity analysis was based on varying chemical control costs within a range of $-100 \%$ to $+100 \%$ at an increment of $5 \%$. Other results were excluded from the table.

${ }^{\mathrm{y}}$ Plants were not included in the NASS Survey.

(pentas, geraniums, zinnia, rudibeckia, and dianthus). This simple aggregation may have ignored some efficiency gains due to economies of scale. Nonetheless, adding up similar crops or crops with similar growth periods in our list may still provide some useful information to growers as a benchmark case.

By providing estimates of revenue and expenses for each crop, this analysis can assist growers in reducing costs in specific areas and in selecting a combination of crops to maximize profits. This method can be easily generalized to estimate the production costs of other annual bedding and perennial plants in different greenhouse sizes. The sensitivity analysis results provide further information regarding crop decisions while accounting for potential risks in input costs. Our results suggest that switching pest management practices might have a deeper impact on profitability due to induced changes in required labor inputs and the associated costs. Although these results provide useful implications for growers, there are several limiting factors that need to be acknowledged. Sale price volatility in this study was not considered by assuming a competitive market with perfect information in the green industry. Yield uncertainty due to pest control was not explicitly modeled; it was only partially captured by the shrinkage rate. Additionally, the sensitivity analysis was restrictive in the sense that we computed the marginal effects by varying one factor at a time while keeping other input factors constant to compare with the baseline case. Future studies may consider relaxing these assumptions and simultaneously taking into account the variations in input variables and price and yield uncertainty to fully explore the impact.

\section{Literature Cited}

Allahyari, M.S., C.A. Damalas, and M. Ebadattalab. 2017. Farmers' technical knowledge about integrated pest management (IPM) in olive production. Agriculture 7(12):101.

Barham, B.L., C. Brock, and J. Foltz. 2006. Organic dairy farms in Wisconsin: Prosperous, modern, and expansive. PATS Research Report No. 16, College of Agricultural and Life Sciences, University of Wisconsin-Madison. 
Beckmann, V., E. Irawan, and J. Wesseler. 2009. The effect of farm labor organization on IPM adoption: Empirical evidence from Thailand. Institutional Change in Agriculture and Natural Resources Discussion Papers 55767, Humboldt University Berlin, Department of Agricultural Economics.

Bethke, J.A. and R.A. Cloyd. 2009. Pesticide use in ornamental production: What are the benefits? Pest Mgt. Sci. 65:345-350.

Biesmeijer, J.C., S.P.M. Roberts, M. Reemer, R. Ohlemüller, M. Edwards, T. Peeters, A.P. Schaffers, and S.G. Potts. 2006. Parallel declines in pollinators and insect-pollinated plants in Britain and the Netherlands. Science 313(5785):351-354.

Brand, M.H. and R.L. Leonard. 2001. Consumer product and service preferences related to landscape retailing. HortScience 36:1111-1116.

Brooker, J., D. Eastwood, C. Hall, K. Morris, A. Hodges, and J. Haydu. 2005. Trade flows and marketing practices within the United States Nursery Industry: 2003. 10 Oct. 2019. Southern Cooperative Series Bulletin 404. <http:// economics.ag.utk/pubs/crops/SCB404.pdf>.

Brumfield, R.G. and M.F. Brennan. 1996. Crop rotational budgets for three cropping systems in the northeastern United States. Rutgers New Jersey Agricultural Experiment Station.

Butler, L.J. 2002. Survey quantifies cost of organic milk production in California. Calif. Agr. 56(202):157-162.

Colla, S.R. and L. Packer. 2008. Evidence for decline in Eastern North American bumblebees (Hymenoptera: Apidae), with special focus on Bombus affinis Cresson. Biodivers. Conserv. 17:1379-1391.

Dalton, T.J., L.A. Bragg, R. Kersbergen, R. Parsons, G. Rogers, D. Kauppila, and A. Wang. 2005. Cost and returns to organic dairy farming in Maine and Vermont for 2004. University of Maine Department of Resource Economics and Policy Staff Paper \#555, Orono, ME.

Dalton, T.J., R. Parsons, R. Kersbergen, G. Rogers, D. Kauppila, L. McCrory, L.A. Bragg, and Q. Wang. 2008. A comparative analysis of organic dairy farms in Maine and Vermont: Farm financial information from 2004-2006. University of Maine, Maine Agricultural and Forest Experiment Station Bulletin 851, Orono, ME.

Dole, J.M. and H.F. Wilkins. 1999. Floriculture: Principles and species. Prentice-Hall, Upper Saddle River, NJ.

Elbert, A., M. Haas, B. Springer, W. Thielert, and R. Nauen. 2008. Applied aspects of neonicotinoid uses in crop protection. Pest Mgt. Sci. 64(12):1099-1105.

Fernandez-Cornejo, J., E.D. Beach, and W. Huang. 1994. The adoption of IPM techniques by vegetable growers in Florida, Michigan and Texas. J. Agr. Appl. Econ. 26(01):158-172.

Fisher, P., A. Hodges, B. Swanekamp, and C. Hall. 2014. The new economics of greenhouse production. Floriculture Research Alliance. 10 Dec. 2019. < http://ellisonchair.tamu.edu/files/2013/ 09/Combined-costing-series.pdf $>$.

Furlan, L. and D. Kreutzweiser. 2015. Alternatives to neonicotinoid insecticides for pest control: Case studies in agriculture and forestry. Environ. Sci. Pollut. Res. 22:135-147.

Gemmill-Herren, B. 2016. Pollination services to agriculture: Sustaining and enhancing a key ecosystem service. Routledge, Oxon and NY.

Ghazoul, J. 2005. Buzziness as usual? Questioning the global pollination crisis. Trends Ecol. Evol. 20(7):367-373.

Goulson, D., E. Nicholls, C. Botías, and E.L. Rotheray. 2015. Bee declines driven by combined stress from parasites, pesticides, and lack of flowers. Science 347(6229), doi: 10.1126/science.1255957.
Hall, C.R. 2010. Making cents of green industry economics. HortTechnology 20:823-835.

Hill, R., G. Nates-Parra, J.J.G. Quezada-Euán, D. Buchori, G. LeBuhn, M.M. Maués, P.L. Pert, P.K. Kwapong, S. Saeed, S.J Breslow, M.C. da Cunha, L.V. Dicks, L. Galetto, M. Gikungu, B.G. Howlett, V.L. Imperatriz-Fonseca, P.O'B. Lyver, B. Martín-López, E. Oteros-Rozas, S.G. Potts, and M. Roué. 2019. Biocultural approaches to pollinator conservation. Nature Sustainability 2:214-222.

Hinson, R.A., A. Owings, J. Black, and R. Harkess. 2008. Enterprise budgets for ornamental crops in plant hardiness zones 8 and 9. Working Paper Series\#2008-14, Department of Agricultural Economics and Agribusiness, Louisiana State University AgCenter, Baton Rouge, LA.

Hodges, A.W., M.A. Palma, and C.R. Hall. 2009. Trade flows and marketing practices within the United States nursery industry, 2008. Southern Cooperative Series Bulletin 411. 10 Dec. 2019. $<$ http://www.greenindustresearch.org $>$.

Hodges, A.W., H. Khachatryan, C.R. Hall, and M.A. Palma. 2015a. Economic contribution of the green industry in the United States in 2013. HortTechnology 25:805-814.

Hodges, A.W., H. Khachatryan, C.R. Hall, and M.A Palma. 2015b. Production and marketing practices and trade flow in the United States green industry in 2013. J. Environ. Hort. 33(3):125-136.

Hovhannisyan, V. and H. Khachatryan. 2016. Ornamental plants in the United States: An economic analysis of household-level demand system. Agribusiness: Intl. J. 33(2):226-241.

International Association of Horticultural Producers (AIPH). 2019. Ornamental horticulture-A growing industry. The International Vision Project, IVP Report. 22 Jan. 2019. <www.aiph.org>.

Jactel, H., V. François, D. Thiéry, A.J. EscobarGutiérrez, E. Gachet, and N. Desneux. the Neonicotinoids Working Group. 2019. Alternatives to neonicotinoids. Environ. Intl. 129:423-429.

Jeschke, P. and R. Nauen. 2008. Neonicotinoidsfrom zero to hero in insecticide chemistry. Pest Mgt. Sci. 64:1084-1098.

Jeschke, P., R. Nauen, M. Schindler, and A. Elbert. 2011. Overview of the status and global strategy for neonicotinoids. J. Agr. Food Chem. 59:2897-2908

Jones, V.P., T.R. Unruh, D.R. Horton, N.J. Mills, J.F. Brunner, E.H. Beers, and P.W. Shearer. 2009. Tree fruit IPM programs in the Western United States: The challenge of enhancing biological control through intensive management. Pest Mgt. Sci. 65(12):1305-1310.

Kay, R.D., W.M. Edwards, and P.A. Duffy. 2011. Farm management. 7th ed. McGraw-Hill Education, New York, NY.

Khachatryan, H., A. Rihn, B. Campbell, C. Yue, C. Hall, and B. Behe. 2017. Visual attention to ecolabels predicts consumer preferences for pollinator friendly plants. Sustainability 9(10): 1743 .

Kleijn, D., R. Winfree, I. Bartomeus, L. G. Carvalheiro, M. Henry, R. Isaacs, A. Klein, C. Kremen, L.K. M'Gonigle, R. Rader, T.H. Ricketts, N.M. Williams, N.L. Adamson, J.S. Ascher, A. Bládi, P. Batáry, F. Benjamin, J.C. Biesmeijer, E.J. Blitzer, R. Bommarco, M.R. Brand, V. Bretagnolle, L. Button, D.P. Cariveau, R. Chifflet, J.F. Colville, B.N. Danforth, E. Elle, M.P.D. Garratt, F. Herzog, A. Holzschuh, B.G. Howlett, F. Jauker, S. Jha, E. Knop, K.M. Krewenka, V. Le Féon, Y. Mandelik, E.A. May, M.G. Park, G. Pisanty, M. Reemer, V. Riedinger, O. Rollin, M. Rundlöf, H.S. Sardiňas, J. Scheper, A.R. Sciligo, H.G. Smith, I. Steffan-Dewenter, R. Thorp, T. Tscharntke, J. Verhulst, B.F. Viana, B.E. Vaissière, R. Veldtman, K.L. Ward, C. Westphal, and S.G.
Potts. 2015. Delivery of crop pollination services is an insufficient argument for wild pollinator conservation. Nat. Commun. 6:7414.

Madigan, J. 2018. Plant \& flower growing in the US. IBISWorld Industry Report 11142.

Nebraska Extension at University of NebraskaLincoln. 2016. Neonicotinoid Insecticides - Pollinators, Plants and Your Garden. 16 Jan. 2020. $<$ https://extension.unl.edu/statewide/cass/Neonictinoid $\% 20$ Insecticides $\% 20-\% 20$ Pollinators $\% 2 \mathrm{C} \% 20$ Plants $\% 20$ and $\% 20$ Your\%20Garden $\% 20 \ldots \% 20$ August $\% 2012 \% 2 \mathrm{C} \% 202018$.pdf $>$.

Noleppa, S. 2017. Banning neonicotinoids in the European Union: An ex-post assessment of economic and environmental costs. HFFA Research Paper 01/2017.

Pisa, L.W., V. Amaral-Rogers, L.P. Belzunces, J.M. Bonmatin, C.A. Downs, D. Goulson, D.P. Kreutzweiser, C. Krupke, M. Liess, M. McField, C.A. Morrissey, D.A. Noome, J. Settele, N. SimonDelso, J.D. Stark, J.P. Van der Sluijs, H. Van Dyck, and M. Wiemers. 2015. Effects of neonicotinoids and fipronil on non-target invertebrates. Environ. Sci. Pollut. Res. 22(1):68-102.

Potts, S.G., J.C. Biesmeijer, C. Kremen, P. Neumann, O. Schweiger, and W.E. Kunin. 2010. Global pollinator declines: Trend, impacts and drivers. Trends Ecol. Evol. 25(6):345-353.

Potts, S.G., V. Imperatriz-Fonseca, and H.T. Ngo. 2016. The assessment report on pollinators, pollination and food production. Intergovernmental Science-Policy Platform on Biodiversity and Ecosystem Services (IPBES).

Rutgers New Jersey Agricultural Experiment Station Farm Management. 2008. Greenhouse costs of production budgets. 12 June 2018. <http:// farmmgmt.rutgers.edu/green-house/greenhouseindex.html $>$.

Sanchez-Bayo, F. and K. Goka. 2014. Pesticide residues and bees-a risk assessment. PLoS One 9(4):E99482.

Schimmenti, E., A. Galati, V. Borsellino, C. Ievoli, C. Lupi, and S. Tinervia. 2013. Behaviour of consumers of conventional and organic flowers and ornamental plants in Italy. HortScience 40:162-171

Stathacos, C.J. and G.B. White. 1981. An economic analysis of New York greenhouse enterprises. Department of Agricultural Economics, Cornell University Agricultural Experiment Station, Cornell University, Ithaca, NY.

Takele, E., B. Faber, M. Gaskell, G. Nigatu, and I. Sharabeen. 2007. Sample costs to establish and produce organic blueberries in the coastal region of Southern California, San Luis Obispo, Santa Barbara, and Ventura Counties, 2007. University of California Cooperative Extension.

UMass Extension Greenhouse Crops \& Floriculture Program, the Center for Agriculture, Food and the Environment, University of Massachusetts Amherst. 2003. Calculating costs for growing media. 7 Oct. 2019. <https://ag.umass.edu/ greenhouse-floriculture/fact-sheets/calculatingcosts-for-growing-media $>$.

USDA NASS. 2015. Census of horticultural specialties (2014). United States Department of Agriculture, National Agricultural Statistics Service (USDA/NASS), Washington, DC.

USDA NASS. 2019. Floriculture crops 2018 summary. United States Department of Agriculture, National Agricultural Statistics Service (USDA) NASS), Washington, DC.

van der Sluijs, J.P., N. Simon-Delso, D. Goulson, L. Maxim, J.M. Bonmatin, and L.P. Belzunces. 2013. Neonicotinoids, bee disorders and the sustainability of pollinator services. Curr. Opin. Environ. Sustain. 5(3-4):293-305. 


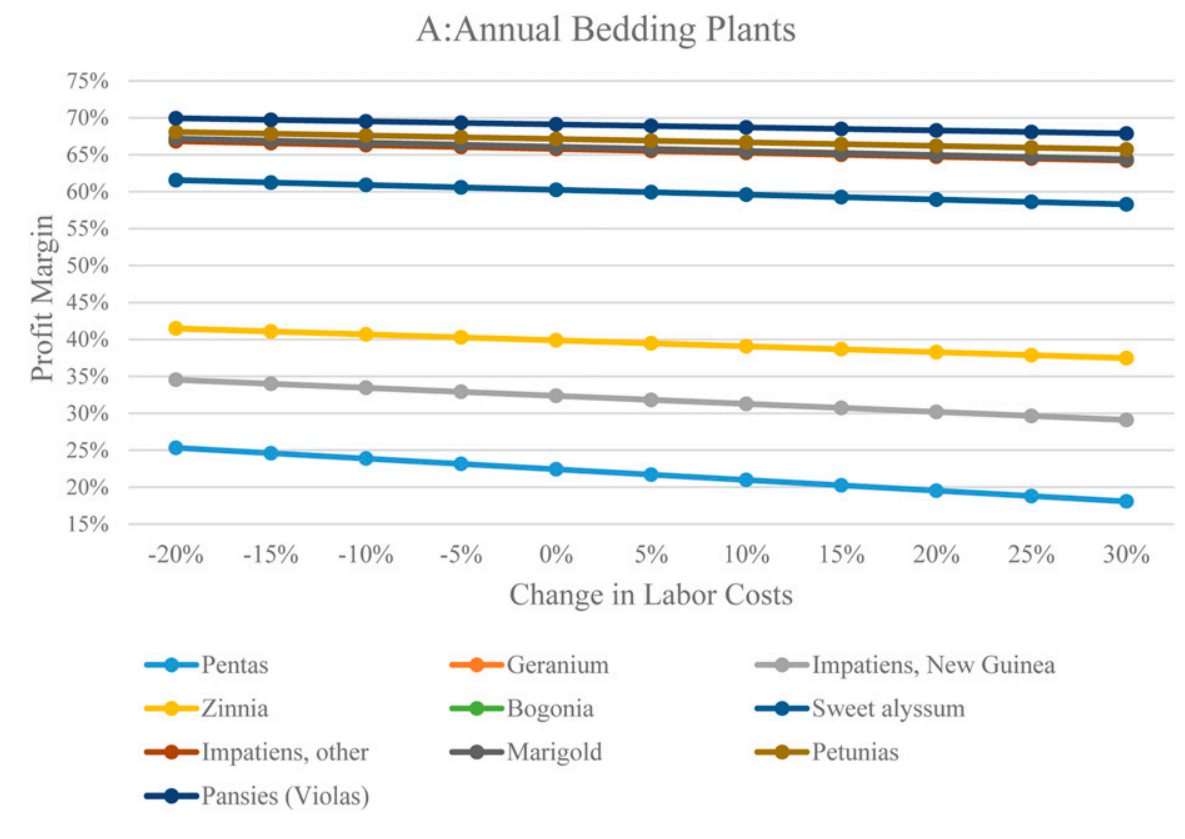

\section{B: Perennial Plants}

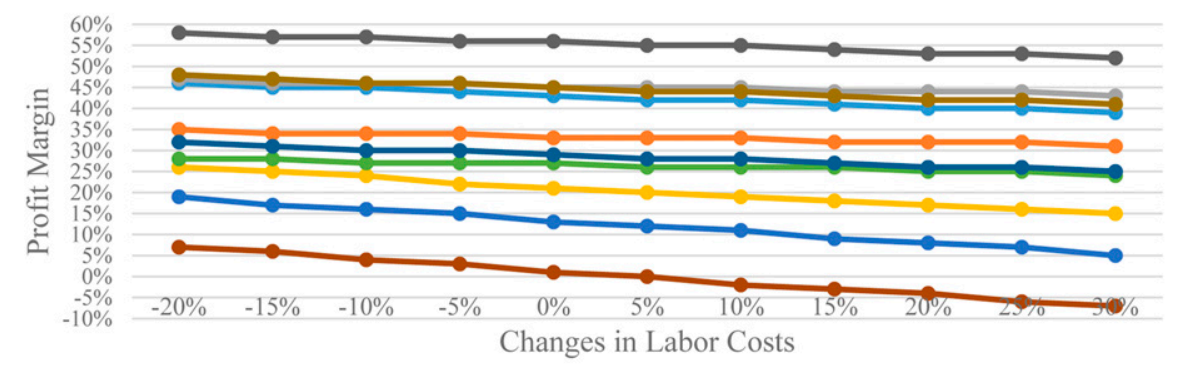

$$
\begin{array}{ll}
\longrightarrow \text { Chrysanthemums (hardy/garden) } & - \text { Hostas } \\
\rightarrow \text { Daylilies } & - \text { Salvia } \\
\rightarrow \text { Dianthus } & - \text { Coral bells (Heuchera) } \\
\rightarrow \text { Echinacea } & - \text { Agastache }
\end{array}
$$

Supplemental Fig. 1. Profit margin sensitivity analysis with uncertainty in labor cost. 


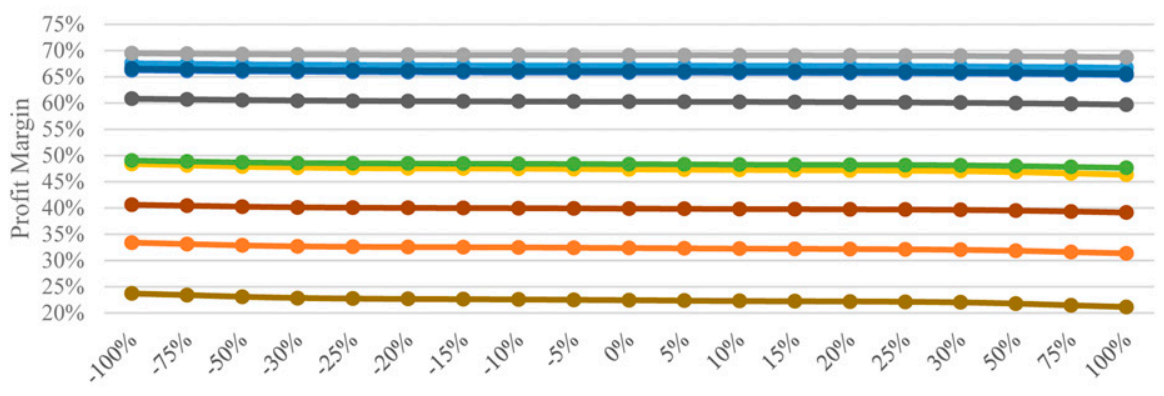

Changes in Agrichemical

$$
\begin{aligned}
& \text {-Petunias } \quad \longrightarrow \text { Geraniums } \quad \longrightarrow \text { Pansies (Violas) } \\
& \longrightarrow \text { Begonia } \quad \longrightarrow \text { Impatiens, other (I. wallerana) } \longrightarrow \text { Impatiens, New Guinea } \\
& \text {-Marigold } \quad \longrightarrow \text { Zinnia } \quad \longrightarrow \text { Sweet Alyssum } \\
& \longrightarrow \text { Pentas }
\end{aligned}
$$

\section{B: Perennial Plants}

\begin{tabular}{|c|c|c|c|c|}
\hline & $\begin{array}{l}\text { Total number } \\
\text { of producers }\end{array}$ & $\begin{array}{c}\text { Number of greenhouse } \\
\text { producers }^{z}\end{array}$ & $\begin{array}{c}\text { Greenhouse production } \\
\operatorname{area}^{\mathrm{y}}\left(1,000 \mathrm{ft}^{2}\right)\end{array}$ & $\begin{array}{l}\text { Avg production } \\
\operatorname{area}^{\mathrm{x}}\left(\mathrm{ft}^{2}\right)\end{array}$ \\
\hline 2015 & 5,913 & 4,139 & 409,384 & 98,900 \\
\hline 2018 & 6,386 & 4,470 & 423,013 & 94,600 \\
\hline 2015 & 2,595 & 1,817 & 371,852 & 204,652 \\
\hline 2018 & 2,792 & 1,954 & 390,478 & 199,835 \\
\hline
\end{tabular}

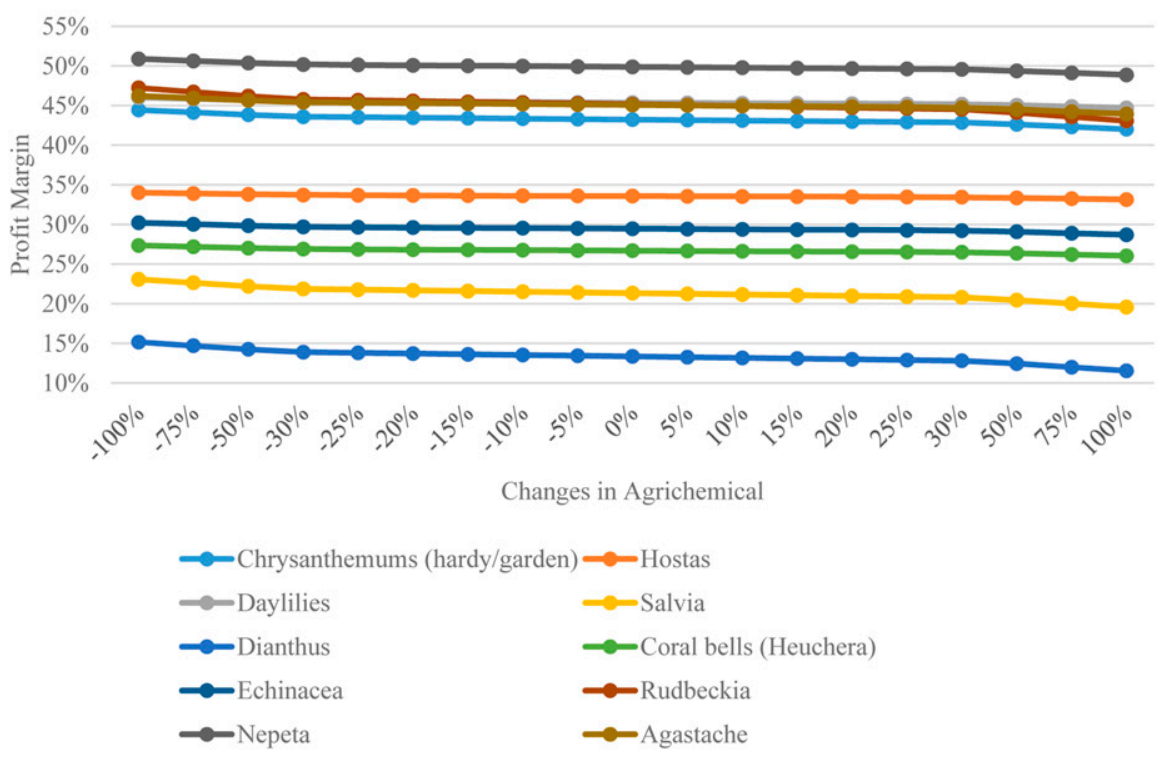

Supplemental Fig. 2. Profit margin sensitivity analysis with uncertainty in agrichemical costs.

Supplemental Table 1. National greenhouse average production area based on Floriculture Crops 2018 Summary (USDA/NASS, 2019).

${ }^{\mathrm{z}}$ Assuming $70 \%$ of the producers are engaged in greenhouse production. The $70 \%$ is based on the 2019 National Neonicotinoid Insecticides Use Survey Conducted by authors.

${ }^{y}$ Authors adopted from the Floriculture Crops 2018 Summary (USDA/NASS, 2019) p. 9 and p. 13.

${ }^{\mathrm{x}}$ Authors calculated using the greenhouse production area divided by the number of greenhouse producers. 